\title{
Role of maspin in cancer
}

\author{
Rossana Berardi, Francesca Morgese, Azzurra Onofri, Paola Mazzanti, Mirco Pistelli, Zelmira Ballatore, Agnese Savini, \\ Mariagrazia De Lisa, Miriam Caramanti, Silvia Rinaldi, Silvia Pagliaretta, Matteo Santoni, Chiara Pierantoni and \\ Stefano Cascinu
}

\begin{abstract}
Maspin (mammary serine protease inhibitor), is a member of the serine protease inhibitor/non-inhibitor superfamily. Its expression is down-regulated in breast, prostate, gastric and melanoma cancers but over-expressed in pancreatic, gallbladder, colorectal, and thyroid cancers suggesting that maspin may play different activities in different cell types. However, maspin expression seems to be correlated with better prognosis in prostate, bladder, lung, gastric, colorectal, head and neck, thyroid and melanoma cancer. In breast and ovarian cancer maspin significance is associated with its subcellular localization: nucleus maspin expression correlates with a good prognosis, whilst in pancreatic cancer it predicts a poor prognosis. Since tumor metastasis requires the detachment and invasion of tumor cells through the basement membrane and stroma, a selectively increased adhesion by the presence of maspin may contribute to the inhibition of tumor metastasis. Furthermore the different position of maspin inside the cell or its epigenetic modifications may explain the different behavior of the expression of maspin between tumors. The expression of maspin might be useful as a prognostic and possibly predictive factor for patients with particular types of cancer and data can guide physicians in selecting therapy. Its expression in circulating tumor cells especially in breast cancer, could be also useful in clinical practice along with other factors, such as age, comorbidities, blood examinations in order to select the best therapy to be carried out. Focusing on the malignancies in which maspin showed a positive prognostic value, therapeutic approaches studied so far aimed to re-activate a dormant tumor suppressor gene by designed transcription factors, to hit the system that inhibits the expression of maspin, to identify natural substances that can determine the activation and the expression of maspin or possible "molecules binds" to introduce maspin in cancer cell and gene therapy capable of up-regulating the maspin in an attempt to reduce primarily the risk of metastasis.

Further studies in these directions are necessary to better define the therapeutic implication of maspin.
\end{abstract}

Keywords: Maspin, Serine protease, Prognosis

\section{Review}

Introduction

Maspin (mammary serine protease inhibitor), is a member of the serine protease inhibitor/non-inhibitor superfamily (serpin), like plasminogen activator inhibitors 1 and 2 and a1-antitrypsin. Maspin gene is located on chromosome 18q21.3-q23 and it was identified for the first time in 1994.

Maspin expression is down-regulated in breast, prostate, gastric and melanoma cancers but over-expressed in pancreatic, gallbladder, colorectal, and thyroid cancers suggesting that maspin may play different activity in

\footnotetext{
*Correspondence: r.berardi@univpm.it

Medical Oncology Unit, Università Politecnica delle Marche, Azienda Ospedaliero-Universitaria Ospedali Riuniti Umberto I, GM Lancisi, G Salesi di Ancona, Via Conca, Ancona 71-60126, Italy
}

different cell types. These conflicting observations might be explained by distinct subcellular localization of maspin in cancer cells (cytoplasmic, nuclear or both cytoplasmicnuclear expression); by interactions with extracellular matrix and its structure and epigenetic modifications [1-4].

A characteristic feature of serpin structure, is a reactive center loop (RCL), a peptide stretch that is located 9-15 residues amino-terminal to the reactive site peptide bond. RCL allows the reactive site to present an optimal configuration for binding, and subsequent inhibiting target protease.

The conformational change is known as the "stressed-to -relaxed" transition. Maspin, however, contains a relatively short, divergent, not highly conserved, hydrophobic RCL not capable of undergoing this transition. Collectively,

\section{望}


these properties place maspin into the non-inhibitory category of the large serpin superfamily and shift the focus away from attempting to identify a target protease as explanation for the biological activities of maspin (Figure 1) [5-7].

Another interesting aspect of Maspin pertains to the $G$ $\alpha$-helix (G-helix), an internal salt bridge or the P1 position of the reactive center loop. The Maspin G-helix is capable of an "open and closed" conformational change inducing redistribution of charged residues within the molecule.

An intact G-helix is absolutely required for the effect of maspin on cell migration, and the effect of the maspin protein can be mimicked by a short peptide corresponding to this structural element. Maspin and the G-helix in isolation are reliant on $\alpha 1$ integrins for their effects on cell migration [8].

Furthermore the action of maspin on cell migration needed a 15-mer G-helix peptide right direct binding to the $\beta 1$ integrin subunit resulting in the inactivation of $\beta 1$ integrins (Figure 2) [9-11].

In fact several studies showed that Maspin elicits changes in the expression of proteins associated with the actin cytoskeleton that predict a less motile and

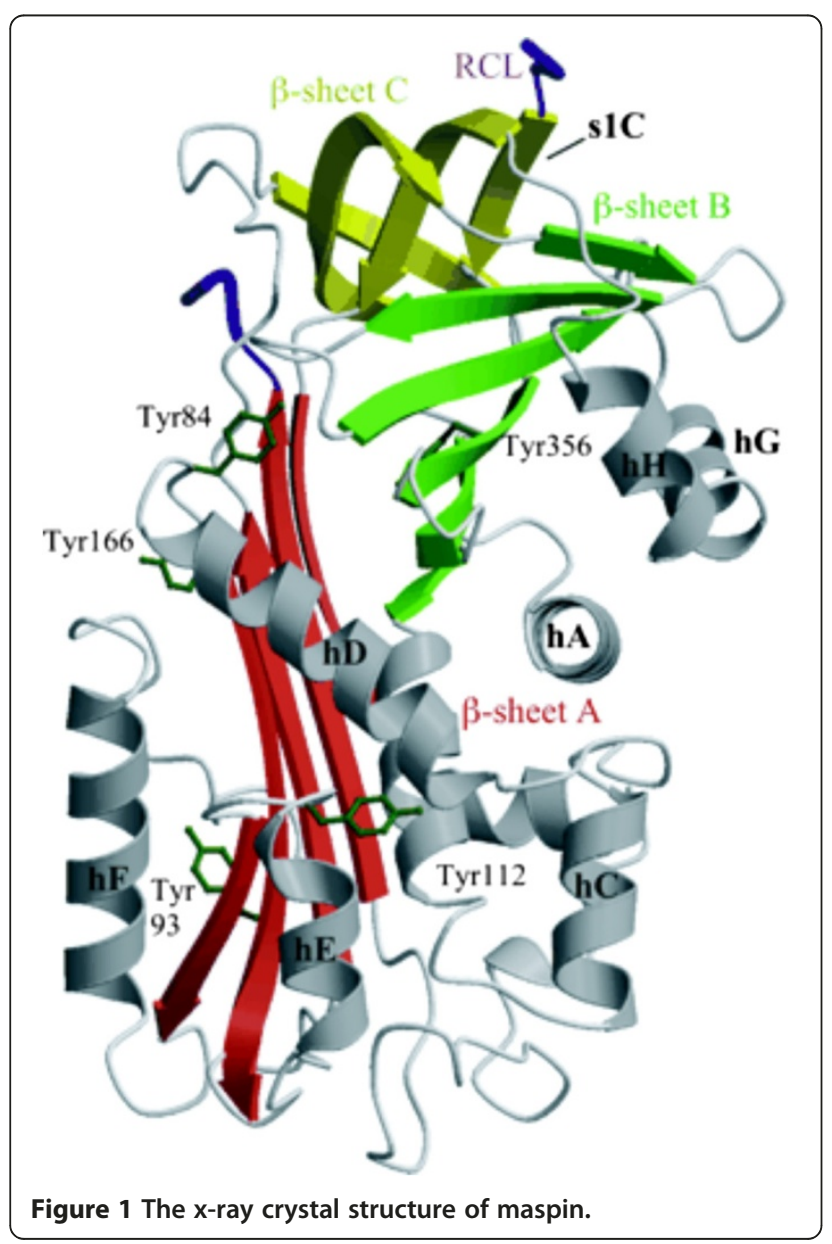

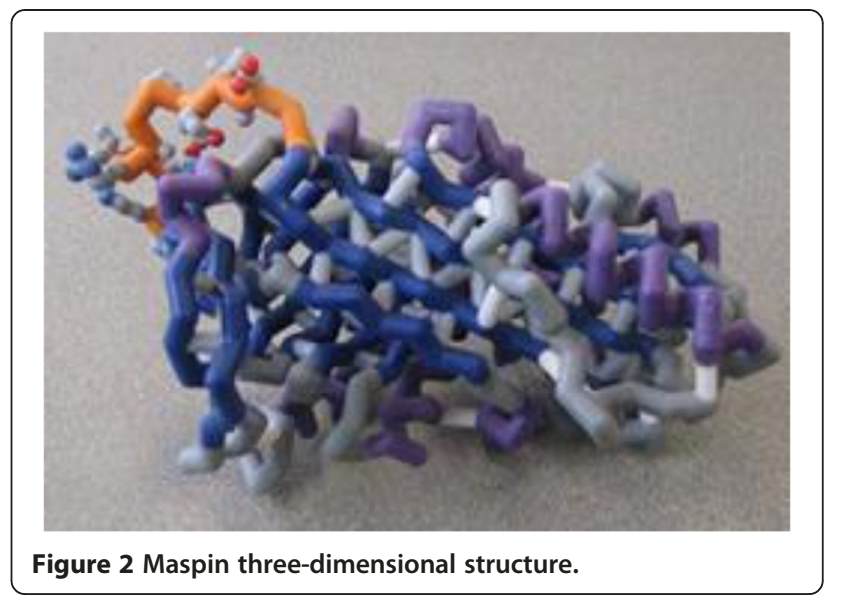

invasive phenotype and reduced metastatic spread. Moreover, RCL appears to mediate binding to a cell surface receptor that promotes cell adhesion to type I collagen and fibronectin [12,13].

To confirm this maspin action time-lapse video microscopic studies showed that recombinant maspin dramatically also inhibited the lamellopodia extension and vectorial translation [14].

Since tumor metastasis requires the detachment and invasion of tumor cells through the basement membrane and stroma, selectively increased adhesion by the presence of maspin may contribute to the inhibition of tumor metastasis (Figure 3) [15-17].

During the process of metastasis, there are consistent changes in gene expression. Studies of genes that are reduced or silenced have yielded surprising insights into in vivo mechanisms of regulating tumor metastasis. This review describes a tumor suppressor gene, Maspin, which is often silenced in cancer cells and exhibits suppressing activity against tumor growth and metastasis. Maspin has been shown to be involved in processes that are important to both tumor growth and metastasis such as cell invasion, angiogenesis, and more recently apoptosis. Hence, many efforts have been devoted to deciphering the molecular mechanism of maspin. While some insights have come from the protease inhibitory effect of maspin, more perceptive results on how maspin may function in suppressing tumor metastasis have come from studies of gene manipulation, protein interactions and global protein profiling [18].

Recent evidence indicates, however, that nuclear localization of maspin in cancer cells is necessary for its tumor suppressor activity and nuclear-localized maspin binds to chromatin are required to effectively prevent cells from metastasizing [19].

About subcellular distribution, Maspin is predominantly cytoplasmic but it also localizes to other cellular compartments and is secreted. Secreted Maspin could bind to 


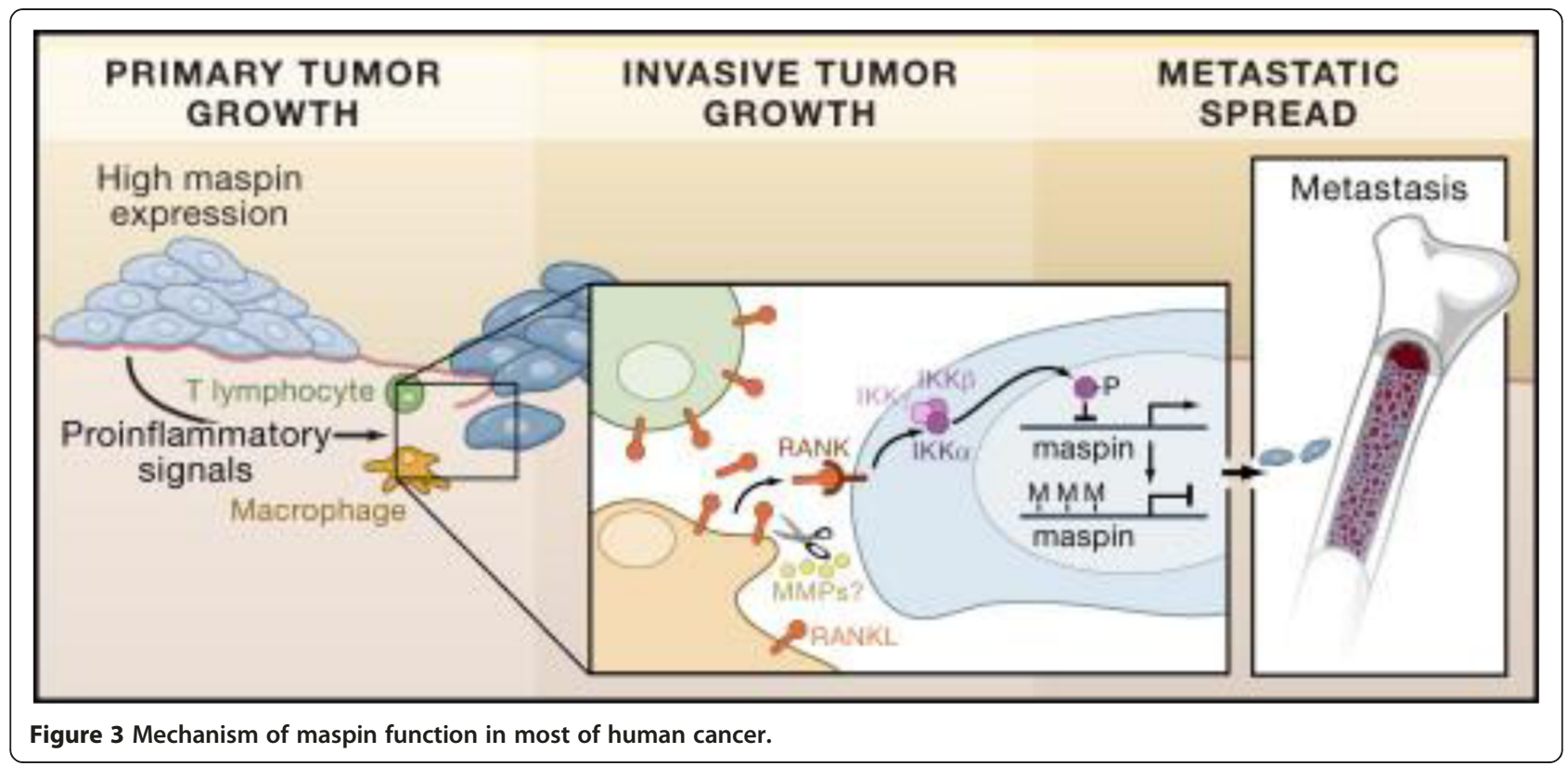

extracellular matrix components. Alternatively, it is possible that maspin exerts its role only in the nucleus at the level of gene or chromatin regulation and thus indirectly affects the cell-matrix interaction or differentiation state and is released only as a consequence of cell damage or necrosis [20-27].

It has recently established that maspin is epigenetically regulated in tissue-specific way. Epigenetic changes of maspin expression involve cytosine methylation, histone, deacetylation, and chromatin accessibility causing loss of gene function [28-30].

Several studies showed that over-expression of maspin in gastric, pancreatic, and ovarian cancers results from promoter $\mathrm{CpG}$ demethylation. This clearly indicates that both methylation and demethylation of maspin promoter could regulate maspin gene expression and could guide the interpretation of overexpression/down regulation associated with negative prognosis. The promoter methylation of the maspin gene leads to gene silencing in several tumors such as breast, thyroid, skin, and colon cancer and it has been recognized as one of the most frequent mechanisms causing loss of gene function. It is noteworthy that in somatic tissues, the majority of CpG islands are methylated, and tumor cells have global DNA hypomethylation compared with their normal counterparts. Hypomethylation is involved in the progression from the premalignant to a fully developed malignancy and leads to activation of genes important for cancer development [31].

\section{Breast cancer}

Maspin is the only pro-apoptotic serpin implicated in apoptosis regulation in breast cancer. The intracellular maspin can translocate to the mitochondria to induce cytochrome $c$ release and caspase activation or modulate expression of Bcl-2 family members [32-40].

In order to confirm maspin tumor suppressor function, several authors investigated in vitro maspin expression in different tissue, from normal gland to metastatic disease. Maspin expression appears to be reduced in advanced stages of breast cancer. In fact, a significant stepwise decrease in maspin expression (and in vascular endothelial growth factor (VEGF) expression) occurred in the sequence DCIS (Ductal Carcinoma In Situ)- invasive cancer - brain-lymph-node-bone metastasis experiments. Myoepithelium, normal breast and fibrocystic change showed a strong maspin expression [41-43].

Even if Maspin absence emerges as an indicator of tumor progression and metastatic potential, recent studies showed that maspin expression was correlated with an aggressive phenotype in the breast cancer and with poor prognosis. Three hypothesis were thought for the aberrant expression of maspin in breast cancer cells: maspin gene alteration with loss of activity; a high intracellular density of maspin resulting in autoinhibition of its function; myoepithelial cell differentiation in cancer cells could contribute to more aggressive phenotype. It is also important to investigate the different subcellular maspin expression. In fact nuclear staining was demonstrated to be significantly associated with better a prognosis than cytoplasmic staining $[44,45]$.

Umekita et al. and Kim et al. examined, 92 and 192 invasive ductal carcinomas respectively. They reported that maspin expression was frequently observed in invasive ductal carcinoma with an aggressive phenotype 
(i.e. high histological grade), and it was a strong indicator of a poor prognosis [46,47].

Conversely, in order to define the significance of subcellular maspin location, Mohsin et al. performed a preliminary study assessing the associations of maspin with other established prognostic factors in invasive breast cancer. In a series of 1068 breast cancer maspin nuclear staining was significantly associated with good prognostic factors rather than cytoplasmic staining [48].

Furthermore the prognostic role of maspin was investigated by Umekita et al. and Lee et al. They examined maspin and p53 expression in 168 and 80 patients with invasive ductal carcinoma, respectively. Large tumor size, high histologic grade, positive p53 status, negative estrogen receptor or progesterone receptor status and poor prognosis were correlated with maspin expression [49-51].

Stark et al. and Maas et al., instead, investigated the potential correlations between maspin expression in primary tumor and in the metastatic sites. They showed that maspin expression is reduced in primary tumors and again decreased in metastasis $[52,53]$.

This finding adds maspin to the list of metastasis suppressor genes potentially involved in the spread of breast cancer metastases (Table 1).

Nevertheless, further investigations are needed to clarify the real mechanism of the aberrant expression of maspin in breast cancer, also in order to use it as a prognostic marker in clinical practice.

\section{Prostate cancer}

In human prostate cancer, maspin expression consistently appears to be down-regulated at the critical transition from non-invasive, low grade to high grade prostate cancer. In particular, the loss of basolateral maspin expression in benign secretory cells, the dramatically up-regulation in High Grade Prostatic Intraepithelial Neoplasia and the progressively decrease in invasive

Table 1 Maspin expression in breast cancer

\begin{tabular}{|c|c|c|c|c|}
\hline Authors & Year & N. patients & Maspin expression & Clinical pathological features/prognosis \\
\hline \multirow[t]{4}{*}{ Umekita et al. } & 2003 & $\begin{array}{l}92 \text { (invasive } \\
\text { breast cancer) }\end{array}$ & 18.5\% positive maspin & $\begin{array}{l}\text { Positive maspin in invasive breast cancer and DCIS = large tumor size, } \\
\text { presence of comedo-necrosis and high grade }\end{array}$ \\
\hline & & $\begin{array}{l}145 \text { (Ductal Carcinoma } \\
\text { In Situ) }\end{array}$ & 9.6\%positive maspin & \\
\hline & & 27 (atypical hyperplasia) & $3.7 \%$ positive maspin & \\
\hline & & 94 (usual hyperplasia) & 0\%positive maspin & \\
\hline \multirow[t]{3}{*}{ Kim et al. } & 2003 & $\begin{array}{l}192 \text { (stage I-II } \\
\text { breast cancer) }\end{array}$ & 34.4\% positive maspin & Positive maspin in all type of invasive breast cancer $=$ high grade \\
\hline & & & $\begin{array}{l}36.4 \% \text { positive maspin in } \\
\text { invasive ductal carcinoma }\end{array}$ & \\
\hline & & & $\begin{array}{l}7.1 \% \text { positive maspin in } \\
\text { invasive lobular carcinoma) }\end{array}$ & \\
\hline \multirow[t]{2}{*}{ Mohsin at al. } & 2003 & 1068 (breast cancer) & $35 \%$ positive cytoplasm & $\begin{array}{l}\text { Positive cytoplasmic maspin = negative ER and PgR, high Mib, } \\
\text { aneuploidy }\end{array}$ \\
\hline & & & 96\% positive nucleus & Positive nuclear maspin = positive ER and PgR \\
\hline \multirow[t]{2}{*}{ Umekita et al. } & 2002 & 168 (breast cancer) & 27.4\% positive maspin & $\begin{array}{l}\text { Positive maspin }=17.4 \% \text { Large tumor size, } 43.4 \% \text { high grade, } 65.2 \% \\
\text { negative ER and PgR, } 43.4 \% \text { positive p53 shorter PFS and OS }\end{array}$ \\
\hline & & & 72.6\% negative maspin & $\begin{array}{l}\text { Negative maspin }=9 \% \text { large tumor size, } 19.6 \% \text { high grade } 35.2 \% \\
\text { negative ER and PgR 20,5\% positive p53, better PFS and OS }\end{array}$ \\
\hline \multirow[t]{2}{*}{ Umekita et al. } & 2011 & $\begin{array}{l}135 \text { (triple negative } \\
\text { breast cancer) }\end{array}$ & 85.9\% positive maspin & Positive maspin $=43.1 \%$ age $\leq 50$ years, $80.2 \%$ high grade \\
\hline & & & 14.1\% negative maspin & Negative maspin $=5.2 \%$ age $\leq 50$ years, $42.1 \%$ high grade \\
\hline \multirow[t]{2}{*}{ Lee et al. } & 2006 & 80 (breast cancer) & $31.3 \%$ positive maspin & $\begin{array}{l}\text { Positive maspin }=24 \% \text { large tumor size, } 52 \% \text { high grade, } 80 \% \text { negative } \\
\text { PgR, Short PFS and OS }\end{array}$ \\
\hline & & & $68.7 \%$ negative maspin & $\begin{array}{l}\text { Negative maspin }=7.2 \% \text { large tumor size, } 21.8 \% \text { high grade, } 41.8 \% \\
\text { negative PgR, better PFS and OS }\end{array}$ \\
\hline \multirow[t]{2}{*}{ Stark et al. } & 2012 & $\begin{array}{l}16 \text { (metastatic } \\
\text { breast cancer) }\end{array}$ & $\begin{array}{l}30 \% \text { positive maspin } \\
\text { in primary tumor }\end{array}$ & \\
\hline & & & $\begin{array}{l}13 \% \text { positive maspin in } \\
\text { brain metastasis }\end{array}$ & \\
\hline \multirow[t]{2}{*}{ Maass et al. } & 2001 & 45 (breast cancer) & $64 \%$ positive maspin & $17.7 \%$ of patients develop metastasis $=75 \%$ negative maspin \\
\hline & & & $36 \%$ negative maspin & \\
\hline
\end{tabular}


cancer are associated with maspin capability to reduce tumor growth, osteolysis and angiogenesis. Furthermore, there is an evidence that maspin inhibits prostate cancerinduced bone matrix remodeling and induces prostate cancer glandular redifferentiation [54-61].

Lovric et al. examined 34 biopsies of prostatic carcinoma. Maspin resulted expressed in the cytoplasm of basal cells of normal prostatic glands, whilst normal luminal cells were inconsistently weakly positive and it was aberrant over-expressed in prostate cancer with a predominance of nuclear presence [62].

On the other hand, Riddick et al. and Machtens et al. analyzed gene expression and clinico-pathologic features in 44 and 84 patients with prostate cancer, respectively. Maspin expression was inversely correlated with the Gleason score and positively correlated with lower tumor stage, more differentiated grade and a lower p53 protein mutation $[63,64]$.

Zou et al. investigated Maspin expression in 97 prostate tumor specimens showing that tumor cells that exhibit histological response to neoadjuvant "hormonal treatment" showed Maspin expression. These data suggest that the androgen withdrawal may unmask Maspin expression in prostate cancer, which frequently lacks Maspin expression (Table 2) [65].

In conclusion, Maspin expression correlates with a better prognosis and may serve as a biomarker for prostate cancer cells responding to the androgen ablation therapy.

\section{Bladder cancer}

Recent evidences seem to correlate a low maspin expression in bladder tumors to an increased tumor cell growth both in vivo and in vitro. In particular, maspin expression was preserved in superficial bladder cancers but significantly decreased in invasive carcinomas. Within the group of invasive cancers, the authors found that maspin expression was associated with good prognosis.

Recently, Lockett et al. showed the essential role of maspin in epithelial homeostasis and that a sub-cellular location of maspin seems to reflect a distinct tumor progression pathway. In particular, the nuclear location of maspin seems to be associated with lower histological grade and longer recurrence free disease [65-79].

Acikalin et al. evaluated the clinical significance of maspin in patients with $\mathrm{T} 1$ bladder cancer. They showed that maspin expression was associated with a longer time to recurrence and progression-free survival (PFS) than maspin-negative group [80].

Furthermore Kramer et al. investigated the role of maspin in transitional cell carcinoma of the bladder as well as its prognostic impact. Specimens from 162 nonmuscle invasive bladder cancer patients treated by transurethral resection were examined. They showed that a low maspin protein expression was correlated with a higher incidence of tumor progression and emphasized a possible clinical role of this novel tumor suppressor gene in transitional cell carcinoma of the bladder [81].

In another study, Friedrich et al. analyzed the expression patterns of maspin in $110 \mathrm{pTa} / \mathrm{pT} 1$ urothelial carcinoma of the bladder and compared them with microvessel density (MVD) evaluated by CD105 and CD34. They found a decreased Maspin expression in a large portion of $\mathrm{pTa} / \mathrm{pT} 1$ bladder tumors and shorter PFS with an increase of MVD in maspin negative cancers [82].

Again, Sugimoto et al. evaluated maspin expression in 65 series of bladder cancer. Maspin expression was significantly correlated with the development of muscle invasive bladder cancer. Their contradictory results were explained by the fact that maspin could contribute to bladder cancer development through DNA methylation and histone deacetylation [83].

Another recent study, focused on the role of Maspin in squamous cell carcinoma (SCC) and transitional cell carcinoma (TCC) of urinary bladder.

In 134 bladder cancer patients, the relationship between clinico-pathological features and Maspin was examined and a high Maspin expression was found in low grade and advanced stage. These results indicated that Maspin expression might predict a better prognosis for bladder carcinoma and it could play a role in tumor progression [84].

Table 2 Maspin expression in prostate cancer

\begin{tabular}{|c|c|c|c|c|}
\hline Authors & Years & N. patients & Maspin expression & Clinical features/prognosis \\
\hline Lovric et al. & 2010 & 34 prostate cancer & $\begin{array}{l}\text { 79\% positive maspin with } \\
\text { nuclear expression }\end{array}$ & \\
\hline Riddick et al. & 2005 & 44 prostate cancer & Not found & Positive maspin $=$ lower Gleason score \\
\hline \multirow[t]{2}{*}{ Machtens et al. } & \multirow[t]{2}{*}{2001} & \multirow[t]{2}{*}{84 prostate cancer } & $58 \%$ positive maspin & \multirow{2}{*}{$\begin{array}{l}\text { Positive maspin = OS: } 78 \text { months, PFS: } 41 \text { months, GIII-IV: 23\%, N1/N2 } \\
9 \% \text { OS }=62 \text { months, PFS }=26 \text { months, GIII-IV }=48 \%, \mathrm{~N} 1 / \mathrm{N} 2=18 \%\end{array}$} \\
\hline & & & $18 \%$ negative maspin & \\
\hline \multirow[t]{2}{*}{ Zou et al. } & \multirow[t]{2}{*}{2002} & \multirow[t]{2}{*}{97 prostate cancer } & $40.2 \%$ positive maspin & \multirow[t]{2}{*}{ Positive maspin $=91.7 \%$ partial response with neoadjuvant therapy } \\
\hline & & & $49.8 \%$ negative maspin & \\
\hline
\end{tabular}


Blandamura et al. evaluated, instead, maspin expression in 111 bladder urothelial papillary neoplasms. Their results showed that a strong expression of maspin is related to a better outcome of papillary neoplasms and this is apparently in contrast with the absence or reduced maspin staining observed in the tumors of a lower histological grade and at pTa stage. This was probably due to the fact that the lower grade papillary neoplasms do not induce maspin activation, whereas high-grade neoplasms exert maspin action in an attempt to restrict tumor aggressiveness. (Table 3) [85].

In conclusion, further studies are needed to define the role of maspin in clinical practice of bladder tumors.

\section{Lung cancer}

Several studies demonstrated that maspin inhibits the survival pathway by influencing the response to cell death in lung cancer cells [86].

Bircan et al. investigated maspin in 63 patients with different histological lung carcinoma. The mean percentage of maspin expression was significantly higher in squamous cell carcinoma and adenocarcinoma, than in small cell lung cancer (SCLC) [87].

Recently, in lung cancer, maspin biological functions have been linked to its subcellular localization. Specifically, a nuclear, opposed to a combined nuclear and cytoplasmic localization has been associated with increased survival in non-small cell lung cancer (NSCLC). Lonardo et al., Frey et al., Woenckhaus et al. and Hirai et al., examined 123 NSCLC, 80 adenocarcinoma, 487 tissue microarrays and 112 specimens, respectively. They found that squamous cell carcinoma showed the highest expression and almost exclusively a combined nuclearcytosolic stain in early stage. In contrast, nuclear maspin alone, correlated with favorable clinico-pathologic features and improved prognosis especially in adenocarcinoma [88-90].

Recently our group showed that maspin expression, with nuclear or cytoplasmic localization, together with smoking history, represented prognostic factors in NSCLC. In particular a significant longer overall survival (OS) was seen in patients with higher compared with lower expression of nuclear maspin, and poorer OS was present in patients with a higher intensity of cytoplasmic staining [91].

In another recent study, Wu et al. analysed the expression of maspin in NSCLC and its relationship to vasculogenic mimicry (VM). A total of 160 specimens of NSCLC were considered in this study. The loss of maspin expression may contribute to the invasion and metastasis of NSCLC and it has a positive relationship to VM in NSCLC [92].

Again, Nakagawa et al., Katakuta et al. and Takanami et al. investigated 210 consecutive patients with stage I-IIIA NSCLC, 55 resected NSCLC patients and 181 patients with curatively resected NSCLC respectively. Enhanced maspin expression was found a significant and independent factor in predicting a favorable prognosis in lung squamous cell carcinoma (Table 4) [93-95].

\section{Ovarian cancer}

An evidence that maspin can inhibit ovarian cancer invasion has been shown in vitro, nevertheless the role

Table 3 Maspin expression in bladder cancer

\begin{tabular}{|c|c|c|c|c|}
\hline Authors & Years & N. patients & Maspin expression & Clinical features/prognosis \\
\hline \multirow[t]{2}{*}{ Acikalin et al. } & 2012 & 68 (T1 bladder cancer) & Not specified & $\begin{array}{l}\text { Positive maspin }=\text { longer PFS and less } \\
\text { recurrence }\end{array}$ \\
\hline & & & & $\begin{array}{l}\text { Negative maspin = shorter PFS and more } \\
\text { recurrence }\end{array}$ \\
\hline \multirow[t]{2}{*}{ Kramer at al. } & 2010 & 162 (pTa-pT1 bladder cancer) & 75.9\% positive maspin & Positive maspin = PFS: 46 months \\
\hline & & & $24.1 \%$ negative maspin & Negative maspin = PFS: 18 months \\
\hline \multirow[t]{2}{*}{ Friedrich et al. } & 2004 & 110 (pTa-pT1 bladder cancer) & $33.6 \%$ positive maspin & $\begin{array}{l}\text { Positive maspin = PFS: } 29 \text { months, MVD: } \\
17.7(\text { CD34) and } 6.0 \text { (CD105)per field }\end{array}$ \\
\hline & & & 66.4\%negative maspin & $\begin{array}{l}\text { Negative maspin = PFS: } 23 \text { months, } \\
M V D=21.7 \text { (CD34) and } 4.2 \text { (CD105)per field }\end{array}$ \\
\hline \multirow[t]{2}{*}{ Sugimoto et al. } & 2004 & $\begin{array}{l}65 \text { (22 transurethral resection and } \\
43 \text { radical resection specimens) }\end{array}$ & $\begin{array}{l}18.2 \% \text { positive maspin in transurethral } \\
\text { resection specimens }\end{array}$ & $\begin{array}{l}\text { Positive } \text { maspin }=\text { progression from invasive } \\
\text { bladder cancer }\end{array}$ \\
\hline & & & $\begin{array}{l}51.2 \% \text { positive maspin in radical } \\
\text { resection specimens }\end{array}$ & \\
\hline \multirow[t]{2}{*}{ Nehad et al. } & 2010 & $\begin{array}{l}134 \text { (56 squamous cell carcinoma }(\mathrm{scc}) \\
\text { and } 78 \text { transitional urinary bladder(tcc)) }\end{array}$ & $\begin{array}{l}53.7 \% \text { positive maspin } \\
(42.8 \% \mathrm{scc} \text { and } 61.5 \% \mathrm{tcc})\end{array}$ & Positive maspin $=91.7 \%$ low grade \\
\hline & & & $46.3 \%$ negative maspin & Negative maspin $=54.8 \%$ high grade \\
\hline \multirow[t]{2}{*}{ Blandamura et al. } & 2008 & 66 (48 pTa e 18 pT1) & $38 \%$ positive maspin & $60.5 \%$ positive maspin have high grade \\
\hline & & & $62 \%$ negative maspin & $22.44 \%$ positive maspin have low grade \\
\hline
\end{tabular}




\begin{tabular}{|c|c|c|c|c|}
\hline Authors & Years & N. patients & Maspin expression & Clinical features/prognosis/predictive factors \\
\hline \multirow[t]{3}{*}{ Bircan et al. } & 2010 & 28 (squamous cell lung cancer) & 89.3\% positive maspin & \\
\hline & & 18 (lung adenocarcinoma) & 77.8\% positive maspin & \\
\hline & & 17 (small cell lung cancer) & $52.9 \%$ positive maspin & \\
\hline \multirow[t]{2}{*}{ Lonardo et al. } & 2005 & 46 (squamous cell lung cancer) & $100 \%$ positive maspin & Positive maspin = almost exclusively nuclear position \\
\hline & & 77 (lung adenocarcinoma) & $93,5 \%$ positive maspin & $\begin{array}{l}\text { Positive nuclear maspin in squamous cell lung cancer = low grade, low proliferative rate, } \\
\text { absence of invasion, negative p53 vs nuclear-cytoplasmic position. }\end{array}$ \\
\hline \multirow[t]{3}{*}{ Frey et al. 2009} & 2009 & 80 (lung adenocarcinoma) & $93.7 \%$ positive maspin & \\
\hline & & & $62.6 \%$ positive nucleus & $\begin{array}{l}\text { Positive nuclear maspin }=36.6 \% \text { proliferative rate, Stage I OS: } 87.7 \pm 6.9 \text { months, } 42.5 \% \\
\text { moderate and poor differantation, } 25,5 \% \text { p53+, } 4.2 \% \text { high VEGF }\end{array}$ \\
\hline & & & $37.3 \%$ positive cytoplasm - nucleus & $\begin{array}{l}\text { Positive cytoplasmic maspin }=56.9 \% \text { proliferative rate, Stage I OS: } 58.7 \pm 6.5 \text { months, } 71.4 \% \\
\text { moderate and poor differantation,53.5\% p53+, 39.2\% high VEGF }\end{array}$ \\
\hline \multirow[t]{3}{*}{ Woenckhaus et al. } & 2007 & 487 (tissue microarrays) & 72.3\% positive maspin & \\
\hline & & & $65.3 \%$ positive nucleus & Positive nuclear maspin $=63.9 \%$ squamous cancer, $16.9 \%$ \\
\hline & & & $37.8 \%$ positive cytoplasm & Positive cytoplasmic maspin $=78.2 \%$ squamous cancer, $6.8 \%$ adenocarcinoma adenocarcinoma \\
\hline \multirow[t]{2}{*}{ Hirai et al. } & 2005 & 112 (non-small cell lung cancer) & $55.3 \%$ positive maspin & Positive maspin $=77.8 \%$ positive cytoplasm Stage III and $36.2 \%$ positive cytoplasm Stage I \\
\hline & & & 44.7\% negative maspin & \\
\hline \multirow[t]{4}{*}{ Berardi et al. } & 2010 & 439 (non-small cell lung cancer) & $85.6 \%$ positive maspin & Positive maspin $=$ longer OS \\
\hline & & & $22.8 \%$ positive nucleus & Positive nuclear maspin = independent prognostic factor \\
\hline & & & $44 \%$ positive cytoplasm & Positive cytoplasmic maspin = especially smokers, lower OS than nuclear position \\
\hline & & & $14.4 \%$ negative maspin & Negative maspin $=$ Lower OS \\
\hline \multirow[t]{3}{*}{ Wu et al. } & 2012 & 160 (non-small cell lung cancer) & $48.1 \%$ positive maspin & $\begin{array}{l}\text { Positive maspin = lower vasculogenic mimicry and microvessel density, longer OS, low Stage, } \\
\text { low grade, low lymphnode metastasis }\end{array}$ \\
\hline & & & $51.9 \%$ negative maspin & $\begin{array}{l}\text { Negative maspin = higher vasculogenic mimicry and microvessel density, lower OS, high } \\
\text { Stage, high grade, lymphnode metastasis }\end{array}$ \\
\hline & & 20 (normal tissue) & 100\% positive maspin & \\
\hline \multirow[t]{2}{*}{ Nakagawa et al. } & 2006 & 210(non-small cell lung cancer) & $73.7 \%$ positive maspin in squamous cancer & Positive maspin $=70.1 \% 5$-years OS \\
\hline & & & $26.3 \%$ negative maspin in squamous cancer & Negative maspin $=41.5 \% 5$-years OS \\
\hline \multirow[t]{2}{*}{ Katakura et al. } & 2006 & 55 (non-small cell lung cancer) & Not found & Positive maspin $=67.7 \%$-years OS \\
\hline & & & & Negative maspin $=41.4 \% 5$-years OS \\
\hline \multirow[t]{5}{*}{ Takanami et al. } & 2008 & 181 (non-small cell lung cancer) & 40.8\%positive maspin & \\
\hline & & & $65.7 \%$ positive maspin in squamous cancer & Positive maspin in squamous cell lung cancer $=52.2 \% 5$-years OS \\
\hline & & & $34.3 \%$ negative maspin in squamous cancer & Negative maspin in squamous cell lung cancer $=24 \%$ OS 5 years OS \\
\hline & & & $22.8 \%$ positive maspin in adenocarcinoma & \\
\hline & & & $59.2 \%$ negative maspin & \\
\hline
\end{tabular}


of maspin in ovarian cancer remains to be demonstrated. However it seems that maspin expression level is low on normal ovarian surface epithelium, while ovarian cancer cell lines expressed high to low level of maspin expression that is also correlated with shorter survival in patients with epithelial ovarian cancer. Maspin expression was predominantly located in the cytoplasm and occasionally in the nucleus of epithelium and cancer cells $[96,97]$.

Klasa-Mazurkiewicz at al. examined 168 ovarian tissue and found maspin level significantly higher in patients with borderline tumors and early stages ovarian cancers when compared with healthy tissues those with benign and metastatic tumors. Over-expression of maspin was found to correlate with early stage of disease in nonserous subtypes of ovarian cancer and with a positive response to chemotherapy. A statistically significant longer PFS was observed in women with high as compared with low expression of maspin. Again Moshira et al. examining 68 ovarian specimens: 7 normal tissue, 18 benign, 14 borderline, 46 malignant epithelial ovarian neoplasm, detected the same results about progression disease [98].

As well as in other tumor types, also in ovarian cancer it is important its localization inside the cell in order to define the role of maspin.

Sopel et al. and Solomon et al. studied 132 and 11 invasive epithelial ovarian carcinomas, respectively. Cytoplasmatic maspin expression was correlated with worse clinico-pathologic features and prognosis rather than rare nuclear maspin expression $[99,100]$.

Few studies compared maspin with VEGF in ovarian carcinoma. In a recent study, over-expression of maspin, VEGFC, and VEGFD was significantly associated with unfavorable clinico-pathologic features and poor prognosis in 60 ovarian carcinoma tissues. Similar results were obtained by Sood et al. that assessed maspin expression in 104 ovarian tissue specimens [101].

Bauerschlag et al. investigated the prognostic role of maspin expression in 87 ovarian cancer specimens. There was significant correlation between cytoplasmic maspin expression and OS. Docetaxel- and paclitaxel-resistant ovarian cell lines showed an even higher level of maspin expression, suggesting an unfavorable role of cytoplasmic maspin in ovarian cancer (Table 5) [102].

\section{Colorectal cancer}

Maspin has been investigated for its hypothetic implication in the cancerogenesis of colorectal cancer, for its probable association with conventional histo-pathological features and for its potential as an independent predictor of survival and response to adjuvant chemotherapy.

Cao et al. investigated the relationship between chronic inflammatory states and neoplasia in 125 specimens included inflammatory bowel disease (IBD) with different grade of dysplasia and also with invasive colorectal cancer. Maspin was found paradoxically over-expressed in both active IBD and colitis-associated dysplasia compared to either inactive IBD or normal colonic mucosa, suggesting a potential role in disease "flare" as well as neoplastic progression [103].

Other recent studies demonstrated a sequential decreased expression rate from adenoma to metastatic colorectal carcinomas and an inverse correlation with p53 and microvessel density [104-106].

Focusing on the clinico-pathologic features associated with maspin, Umekita et al. studied expression of maspin in colorectal adenocarcinomas from 104 patients and observed that maspin was significantly correlated with the depth of invasion, higher Dukes' classification and highgrade tumor budding. These results suggest that the expression of maspin may correlate with the aggressiveness of colorectal adenocarcinomas [107].

On the other hand, Fung et al. examined 450 resected colorectal cancer finding a stronger expression in right than in left-sided tumors and a stronger expression in high-grade tumors [108].

Regarding relationship between maspin, other biomarker and a possible target therapy, Gurzu at al. evaluated maspin, p53 and other biomarker expression in 110 cases with colorectal cancer with the aim to correlate maspin with angiogenesis and 5-Fluorouracil (5-FU) therapy. They found a correlation with tumor stage and microsatellite status. Therefore maspin nuclear expression, associated with p53 ones, might be used either to select the high-risk microsatellite stable (MSS) colorectal carcinomas diagnosed in Stage II or those MSI cases which can respond to 5-FU [109].

In another recent study on 156 colorectal cases, significant correlations between cytoplasmic expression and high tumor grade and between nuclear expression, high tumor budding and worse OS, were shown. These findings suggest a compartment-dependent function of maspin in colorectal cancer, which can be useful in identifying stage II cases with a higher risk for fatal outcome with a possible benefit from adjuvant chemotherapy [110].

Again Dietmaier et al. investigated nuclear maspin expression in 172 primary stage III colon cancers showing a significant treatment benefit from 5-FU -based chemotherapy in patients with primary tumors expressing Maspin in the nucleus. These data could be useful, if confirmed in a prospective study, to select patients to receive 5-FU treatment or an alternative (non-5-FU based) adjuvant therapy regime (Table 6) [111].

\section{Gastric cancer}

In human gastric cancer the molecular aspect of carcinogenesis and progression remains elusive. Data are 
Table 5 maspin expression in ovarian cancer

\begin{tabular}{|c|c|c|c|c|}
\hline Authors & Years & N. patients & Maspin expression & Clinical features/prognosis \\
\hline \multirow[t]{5}{*}{$\begin{array}{l}\text { Klasa-Mazurkiewicz } \\
\text { et al. }\end{array}$} & 2009 & 76 (ovarian cancer) & $82.9 \%$ positive maspin & $\begin{array}{l}\text { Positive maspin = OS and PFS longer than maspin } \\
\text { negative tumor. }\end{array}$ \\
\hline & & 8 (Krukemberg tumor) & $87.2 \%$ positive maspin & \\
\hline & & 10 (borderline) & $90 \%$ borderline & \\
\hline & & 42 (benign tumor) & 78.6\% positive maspin & \\
\hline & & 32(normal tissue) & $53.1 \%$ positive maspin & \\
\hline \multirow[t]{3}{*}{ Moshira et al. } & 2005 & $\begin{array}{l}\text { 46(ovarian cancer) } \\
14 \text { (borderline) }\end{array}$ & $\begin{array}{l}65.9 \% \text { positive maspin }=69 \% \text { positive } \\
\text { cytoplasm, } 3.4 \% \text { positive nucleus and } \\
27.6 \% \text { positive nucleus and cytoplasm }\end{array}$ & \\
\hline & & 18(benign tumor) & $\begin{array}{l}57.1 \% \text { positive maspin }=37.5 \% \text { positive } \\
\text { cytoplasm and } 62.5 \% \text { positive nucleus } \\
\text { and cytoplasm }\end{array}$ & \\
\hline & & & 100\% positive cytoplasm & \\
\hline \multirow[t]{3}{*}{ Sopel et al. } & 2010 & 132 (ovarian cancer) & $88.6 \%$ positive maspin & \\
\hline & & & $22 \%$ positive nucleus & $\begin{array}{l}\text { Positive nuclear maspin = low tumor grade, } \\
\text { less distant metastasis, low Figo stage, longer OS }\end{array}$ \\
\hline & & & 12.9\% positive cytoplasm & $\begin{array}{l}\text { Positive cytoplasmic maspin = high tumor } \\
\text { grade, probably distant metastasis, high Figo } \\
\text { stage, shorter OS }\end{array}$ \\
\hline \multirow[t]{4}{*}{ Solomon et al. } & 2006 & $\begin{array}{l}118 \text { (serous ovarian } \\
\text { cancer) }\end{array}$ & $81.4 \%$ positive maspin & \\
\hline & & & $21.2 \%$ positive nucleus & $\begin{array}{l}\text { Positive nuclear maspin = lower VEGF and } \\
\text { COX-2, OS:1803 days }\end{array}$ \\
\hline & & & $60.2 \%$ positive cytoplasm & $\begin{array}{l}\text { Positive cytoplasmic maspin = higher VEGF } \\
\text { and COX-2, OS: } 637 \text { days }\end{array}$ \\
\hline & & & 18.6\% negative maspin & Negative maspin $=$ OS:1146 days \\
\hline \multirow[t]{2}{*}{ Bolat et al. } & 2008 & 60 (ovarian cancer) & 88.3\% positive cytoplasm & $\begin{array}{l}\text { Positive maspin = high VEGF, high grade, high } \\
\text { clinical stage, ascite, lymphnode methastasis }\end{array}$ \\
\hline & & & $11.7 \%$ positive nucleus-cytoplasm & \\
\hline \multirow[t]{3}{*}{ Sood et al. } & 2002 & 80(ovarian cancer) & $71 \%$ positive maspin & $\begin{array}{l}\text { Positive maspin = shorter OS, } 63.3 \% \text { high grade } \\
\text { and } 90 \% \text { ascite }\end{array}$ \\
\hline & & 10 (borderline) & $26.6 \%$ positive nucleus & Positive nuclear maspin $=$ longer OS \\
\hline & & 14 (benign tumor) & & \\
\hline \multirow[t]{2}{*}{ Bauerschlag et al. } & 2010 & 87 (ovarian cancer) & Not found & $\begin{array}{l}\text { Positive maspin = OS: } 28 \text { months and platinum-therapy } \\
\text { resistance }\end{array}$ \\
\hline & & & & Negative maspin $=$ OS: 57 months \\
\hline
\end{tabular}

very few but it seems that maspin up-regulation may cause a retarding cell proliferation [112].

Wang et al. investigated maspin expression in 113 gastric cancer and compared it with clinical parameters, MVD and Caspase-3 expression. Cancer less frequently expressed maspin than normal mucosa and dysplasia. Maspin expression showed a significantly negative correlation with invasive depth, metastasis, Lauren's and Nakamura's classification and MVD, but a positive correlation with expression of Caspase-3 in gastric cancer [113].

In another recent study in 152 cases of gastric cancer, an inverse relationship between maspin and p53 expression was documented. Moreover maspin expression showed a negative association with histologic grade, depth of invasion, metastasis, and TNM stage. Interestingly, patients with nuclear and cytoplasmic maspin expression presented a longer survival than those with only cytoplasmic expression (Table 7) [114].

On the basis of all the above mentioned results, Maspin expression could be considered as an effective and objective marker to reveal biological behaviors of gastric cancer and it could become an useful marker in the future.

\section{Pancreatic cancer}

Unlike other malignant tumors, precancerous pancreatic lesions and pancreatic cancer present up-regulation of maspin gene expression, therefore maspin could be 
Table 6 Maspin expression in colorectal cancer

\begin{tabular}{|c|c|c|c|c|}
\hline Authors & Years & N. patients & Maspin expression & Clinical features/prognosis/predictive factors \\
\hline \multirow[t]{4}{*}{ Cao et al. } & \multirow[t]{4}{*}{2005} & $\begin{array}{l}25 \text { (colorectal cancer } \\
\text { and IBD) }\end{array}$ & 88\%positive maspin & \\
\hline & & 51 (active chronic IBD) & $92 \%$ positive maspin & \\
\hline & & 30 (inactive chronic IBD) & $43 \%$ positive maspin & \\
\hline & & 9(normal mucosa) & $11 \%$ positive maspin & \\
\hline \multirow[t]{3}{*}{ Song et al. } & \multirow[t]{3}{*}{2002} & 66 (colorectal cancer) & $75.5 \%$ positive maspin & $\begin{array}{l}\text { Positive maspin in colorectal cancer }=44.7 \% \text { mutant } \\
\text { p53 expression, microvessel density }=181.1+/-54.2\end{array}$ \\
\hline & & \multirow[t]{2}{*}{ 24(adenoma) } & $24.5 \%$ negative maspin & $\begin{array}{l}\text { Negative maspin in colorectal cancer }=\text { microvessel } \\
\text { density }=256.1+/ 75.4\end{array}$ \\
\hline & & & $91.7 \%$ positive maspin & Positive maspin in adenoma $=0 \%$ mutant p53 expression \\
\hline \multirow[t]{3}{*}{ Jiang-tao et al. } & \multirow[t]{3}{*}{2009} & 50 (colorectal cancer) & $62 \%$ positive maspin & \multirow{3}{*}{$\begin{array}{l}\text { Positive maspin in colorectal cancer }=\text { no association with positive } \\
\text { lymphnode, higher Duke's stage or mutant p53 expression }\end{array}$} \\
\hline & & 20 (adenoma) & $90 \%$ positive maspin & \\
\hline & & 20 (normal mucosa) & 95\%positive maspin & \\
\hline \multirow[t]{3}{*}{ Zheng et al. } & \multirow[t]{3}{*}{2007} & 119 (colorectal cancer) & 95\% positive maspin & \multirow{3}{*}{$\begin{array}{l}\text { Positive maspin in colorectal cancer }=\text { no liver metastasis }=89 \% \\
\text { positive maspin }\end{array}$} \\
\hline & & 22 (adenoma) & 93\%positive maspin & \\
\hline & & 118 (normal mucosa) & 69\%positive maspin & \\
\hline Umekita et al. & 2006 & 104 (colorectal cancer) & $\begin{array}{l}66 \% \text { positive maspin } \\
(15 \%=\mathrm{T} 1-\mathrm{T} 2 \text { and } 78.5 \%=\mathrm{T} 3-\mathrm{T} 4)\end{array}$ & $\begin{array}{l}\text { Positive maspin }=44.2 \% \text { absent tumor budding, } 32.7 \% \\
\text { Duke's stage B }\end{array}$ \\
\hline Fung et al. & 2010 & 450 (colorectal cancer) & $\begin{array}{l}\text { 81\%positive cytoplasm } \\
80 \% \text { positive nucleus }\end{array}$ & Positive maspin = right colon and high-grade tumor \\
\hline Gurzu et al. & 2012 & 101 (colorecatal cancer) & $60 \%$ positive maspin & Positive maspin = Stage $\|-\| \|$ \\
\hline \multirow[t]{2}{*}{ Markl et al. } & \multirow[t]{2}{*}{2010} & \multirow{2}{*}{$\begin{array}{l}156 \text { (colorectal } \\
\text { cancer stage I-II) }\end{array}$} & $48 \%$ positive nucleus & Positive nuclear maspin $=$ pT3 OS $=40$ months \\
\hline & & & 72\% positive cytoplasm & Positive cytoplasmic maspin = pT3 OS = 63 months \\
\hline \multirow[t]{4}{*}{ Dietmaier et al. } & \multirow[t]{4}{*}{2006} & \multirow[t]{4}{*}{172 (colorectal cancer) } & $44.4 \%$ negative nucleus & Negative nuclear maspin = OS: $79.2 \%$, OS after 5FU: $32.5 \%$ \\
\hline & & & $55.6 \%$ positive nucleus & Positive nuclear maspin = OS:66.6\%, OS after 5FU: $71.7 \%$ \\
\hline & & & $24.1 \%$ negative cytoplasm & \\
\hline & & & 75.9\% positive cytoplasm & \\
\hline
\end{tabular}

considered a new factor associated with pancreatic cancer. Liu et al. and Maass at al. examined 102 and 29 specimens of pancreatic tissue and demonstrated that more than $90 \%$ of cases of ductal adenocarcinoma as well as all high-grade precancerous lesions (PanIN3) were positive for maspin, and normal pancreatic ducts and low-grade precancerous lesions were usually negative for maspin (Table 7) [115].

These data show that maspin may play an important role in the carcinogenesis, tumor invasion, metastasis, and angiogenesis of pancreatic cancer. Its relationship to carcinoma of the pancreas opens a new angle to the discussion on its function in cancer [116].

\section{Gallbladder cancer}

There are few published data focusing on maspin expression in gallbladder cancer, but there is an evidence of maspin implication in cholelithiasis-intestinal metaplasia-dysplasia-carcinoma sequence and in the early step of gallbladder cancerogenesis.
In a recent study on 69 patients with cholelithiasis and 30 patients with gallbladder cancer without cholelithiasis, a positive immunoreactivity for maspin was significantly associated with the presence of intestinal metaplasia in patients with cholelithiasis. These data could support the assumption that intestinal metaplasia of the gallbladder may predispose to gallbladder carcinoma [117].

Furthermore Kim et al. compared the pattern of maspin expression in 101 early and advanced gallbladder cancers. The positivity of maspin expression was found almost in half of gallbladder cancers, whereas no maspin was expressed in adenomas and normal mucosa of gallbladder (Table 7) [118].

\section{Head and neck cancer}

Maspin seems to be an important prognostic factor also in head and neck cancer. In particular some studies revealed that the subcellular location seems to make the difference. Nuclear expression is a positive prognostic factor rather than cytoplasmic location $[119,120]$. 
Table 7 maspin expression in gastric, pancreatic and gallbladder cancer

\begin{tabular}{|c|c|c|c|c|}
\hline Authors & Years & N. patients & Maspin expression & Clinical features/prognosis/predictive factors \\
\hline \multirow[t]{2}{*}{ Wang et al. } & 2004 & 113 (gastric cancer) & $50.5 \%$ positive maspin & $\begin{array}{l}\text { Positive maspin }=T 4: 35.9 \% \text {, metastasis: } 34.3 \% \text {, } \\
\text { subtype diffuse: } 42.1 \% \text {, undifferentiated: } 40 \%\end{array}$ \\
\hline & & & 49.5\% negative maspin & $\begin{array}{l}\text { Negative maspin }=T 4: 64.1 \% \text {, metastasis: } 65.7 \% \text {, } s \\
\text { ubtype diffuse: } 57.9 \% \text {, undifferentiated: } 60 \%\end{array}$ \\
\hline \multirow[t]{2}{*}{ Lee et al. } & 2008 & 152 (gastric cancer) & 71.7\% positive maspin & \\
\hline & & & $29.3 \%$ negative maspin & $\begin{array}{l}\text { Negative maspin = undifferentiated, high stage, } \\
\text { metastasis and invasion depth, positive p53 }\end{array}$ \\
\hline Liu et al. & 2012 & 102 (pancreatic cancer) & $98 \%$ positive maspin & \\
\hline \multirow[t]{2}{*}{ Maas et al. } & 2001 & 24 (pancreatic cancer) & 96\% positive maspin & \\
\hline & & 5 (Panln3) & $100 \%$ positive maspin & \\
\hline \multirow[t]{2}{*}{ Maesawa } & 2006 & 69 (cholelithiasis) & 14\% positive maspin & \\
\hline & & 14 (cholelitiasis + intestinal metaplasia) & 64\%positive maspin & \\
\hline \multirow[t]{3}{*}{ Kim et al. } & 2012 & 101 (gallbladder cancer) & 59.4\% positive maspin & \\
\hline & & 25(adenoma) & 100\% negative maspin & \\
\hline & & 10 (normal gallbladder) & 100\%negative maspin & \\
\hline
\end{tabular}

Yoshizawa et al. and Iezzi et al. investigated the possible correlation between clinico-pathologic findings and maspin expression in 54 and 89 oral squamous cell carcinoma, respectively. Maspin was associated with a better survival rate, but a negative correlation with type of invasion, T-stage, lymph-node metastasis and differentiation grade was found [121-123].

Furthermore the cytoplasmic localization was significantly associated with a high risk of disease disseminating to neck lymph-nodes in 56 consecutive cases of oral carcinoma and the nuclear expression was correlated with lower loco-regional recurrence rate and a longer disease-free survival after treatment in elderly patient with laryngeal carcinoma (Table 8) [124,125].
In conclusion, maspin may represent an useful marker to identify the potential for progression of head and neck cancer, since lower immunoreactivity is associated with larger tumors and a greater invasive potential. Furthermore in head and neck cancer it is necessary to clarify the mechanisms between maspin expression and progression of tumor in order to apply to clinical applications.

\section{Thyroid cancer}

Maspin expression was investigated also in thyroid neoplasms originating in follicular cells. Some studies showed that neither normal follicular cells nor stromal cells expressed maspin. Papillary and follicular

Table 8 maspin expression in head and neck cancers

\begin{tabular}{|c|c|c|c|c|}
\hline Authors & Year & N. patients & Maspin expression & Clinical pathological features/prognosis \\
\hline \multirow[t]{2}{*}{ Yoshizawa et al. } & 2011 & 54 (OSCC) & $64.8 \%$ positive maspin & Positive maspin $=77.8 \%$ OS \\
\hline & & & $35.2 \%$ negative maspin & Negative maspin $=29.4 \%$ OS \\
\hline Yoshizawa et al. & 2009 & $71(\mathrm{OSCC})$ & $64.8 \%$ positive maspin & $\begin{array}{l}\text { Positive maspin }=100 \% \text { low grade, } 93.3 \% \text { no } \\
\text { lymphnode metastasis, better OS }\end{array}$ \\
\hline lezzi et al. & 2007 & $89(\mathrm{OSCC})$ & Not found & $\begin{array}{l}\text { Positive maspin = low grade, negative lymphnode, } \\
\text { high stage(?) }\end{array}$ \\
\hline \multirow[t]{5}{*}{ Marioni et al. } & 2008 & $56(\mathrm{OSCC})$ & $58.9 \%$ positive maspin & \\
\hline & & & $5.3 \%$ positive nucleus & \\
\hline & & & 1.8\% positive cytoplasm-nucleus & \\
\hline & & & $51.8 \%$ positive cytoplasm & Positive cytoplasmic maspin $=61 \%$ pN0 and $33 \%$ pN+ \\
\hline & & & $41.1 \%$ negative maspin & \\
\hline \multirow[t]{2}{*}{ Marioni et al. } & 2011 & 68 (laryngeal cancer) & Not found & $\begin{array}{l}\text { Positive nucleus }=22.7 \% \text { lower recurrence and PFS: } \\
44.5 \pm 27.5 \text { months }\end{array}$ \\
\hline & & & & $\begin{array}{l}\text { Positive cytoplasm and cytoplasm-nucleus }=44.6 \% \\
\text { longer recurrence and PFS: } 34 \pm 27.5 \text { months }\end{array}$ \\
\hline
\end{tabular}


carcinomas expressed maspin in significantly higher incidence than those with pure papillary or follicular patterns. These findings indicate that maspin expression is directly associated with prognosis in this setting [126].

Boltze et al. and Tahany et al. detected maspin in 230 and 63 different histological thyroid tissue, respectively, showing that its expression was typical of papillary thyroid tumor, it was associated with tumor multicentricity, vascular and lymphatic invasion, as well as lymph-node metastasis and it was weakly expressed in follicular cancer and absent in normal tissue and in undifferentiated cancers. Maspin expression is a special feature of papillary thyroid carcinomas; promotor methylation-caused maspin repression plays a major role in gene balance and in the process of tumor determination. Therefore maspin could possibly act as a clinically relevant inhibitor of tumor progression, preventing local invasiveness and further systemic progression of papillary thyroid carcinomas $[127,128]$.

Data regarding the relation between maspin expression and clinico-pathological parameters need to be further confirmed on a larger scale with a longer follow up of patients in order to evaluate its relationship with clinical outcome including OS, disease free survival as well as tumor recurrence (Table 9) [129].

\section{Melanoma}

In melanoma, Maspin was found to have a tumorsuppressor function. Previous reports showed that early hypermethylation of the Maspin promoter might play a role in silencing Maspin. In particular Maspin promoter activity was significantly increased after the thrombin receptor protease activated receptor-1 (PAR-1) silencing, suggesting that PAR1 negatively regulates Maspin at the transcriptional level Maspin tumor-suppressor gene in the acquisition of the metastatic melanoma phenotype [130-133].

Wada et al. investigated maspin expression in five melanoma cell lines, in a normal human epidermal melanocyte cell line, and in 80 surgically resected tumors. Their results suggest that maspin expression in normal skin melanocytes and melanocytic nevi may be repressed, whereas maspin is aberrantly expressed in a subset of melanoma cells by epigenetic modification. In particular Chua et al. in 77 melanoma samples found maspin presence in the radial growth phase in melanoma, and a lost maspin expression in the transition from the radial growth phase to the vertical growth phase of melanoma (Table 9) [134,135].

\section{Future perspectives}

The expression of maspin might be useful as a prognostic and possibly predictive factor for patients with particular types of cancer and data can guide physicians in selecting therapy. Its expression in circulating tumor cells especially in breast cancer, could be also useful in clinical practice along with other factors, such as age, comorbidities, blood examinations in order to select the best therapy to be carried out.

Detecting maspin mRNA amplification by RT-PCR, several authors, as mentioned above, showed maspin in normal breast epithelial cells and in primary and metastatic breast cells, but not in the peripheral blood of healthy donors. Furthermore, they found the presence of circulating maspin-positive cells, potentially neoplastic, in the peripheral blood of patients with breast cancer

Table 9 Thyroid cancer and melanoma

\begin{tabular}{|c|c|c|c|c|}
\hline Authors & Years & N. patients & Maspin expression & Clinical features/prognosis/predictive factors \\
\hline \multirow[t]{2}{*}{ Boltze et al. } & 2004 & 68 (papillary carcinomas) & 70.5\% positive maspin & $\begin{array}{l}\text { Positive maspin in papillary cancer }=2 \% \text { p53+, } 83 \% 110 \text { months } \\
\text { OS, Recurrence free disease: } 60 \text { months }\end{array}$ \\
\hline & & 38 (follicular carcinomas) & $100 \%$ negative maspin & $\begin{array}{l}\text { Negative maspin in follicular carcinomas }=80 \% \mathrm{p} 53+, 40 \% \\
110 \text { months OS, Recurrence free disease :40months }\end{array}$ \\
\hline \multirow[t]{2}{*}{ Tahany et al. } & 2006 & $63($ thyroid specimes $)=$ & $28.5 \%$ positive maspin & $\begin{array}{l}\text { Positive maspin }=72 \% \text { papillary thyroid, } 61,1 \% \text { positive cytoplasm } \\
\text { and positive nucleus, } 11.1 \% \text { positive nucleus and } 27.8 \% \text { positive } \\
\text { cytoplasm, }\end{array}$ \\
\hline & & 25 papillary carcinoma & $71.5 \%$ negative maspin & \\
\hline \multirow[t]{2}{*}{ Wada et al. } & 2004 & 45 (malignant melanoma) & 12.5\% positive maspin & \\
\hline & & & $87.5 \%$ negative maspin & $\begin{array}{l}\text { Negative maspin in melanoma }=83 \% \text { trunk, } 89 \% \text { extremites, } 89 \% \\
\text { acral, } 86 \% \text { lentigo maligna melanoma, 100\% nodular melanoma, } \\
75 \% \text { superficial spreading, 100\% thickness } 1.0-4.0 \text { and }>4 \text { mm, } \\
\text { 100\% II-III-IV stage }\end{array}$ \\
\hline \multirow[t]{2}{*}{ Chua et al. } & 2009 & 77(malignant melanoma) & 59.7\% positive maspin & $\begin{array}{l}\text { Positive maspin = less microvessel density, } 78 \% \text { thin melanoma, } \\
46 \% \text { thick melanoma }\end{array}$ \\
\hline & & & $35.1 \%$ negative maspin & $\begin{array}{l}\text { Negative maspin }=\text { high microvessel density, } 22 \% \text { thin melanomas, } \\
54 \% \text { thick melanoma }\end{array}$ \\
\hline
\end{tabular}


undergoing conventional-dose chemotherapy. On the basis of these observations, they assessed a possible mobilizing effect of chemotherapy, delivered at standard doses, on mammary cells of potential neoplastic origin. Thus suggesting that the detection of circulating breast cells could have prognostic significance, as it was associated with a higher risk of early relapse or disease progression for patients with limited or stage IV disease, respectively. The results of these studies should be interpreted with caution, and larger studies with longer follow-up are required to definitely establish the clinical usefulness of the test [136-139].

Moreover, maspin expression was found directly correlated with treatment including carboplatin plus vinorelbine combined with radiotherapy in primary head and neck squamous cell carcinoma [140].

In some cases, the subcellular localization could predict response to chemotherapy. In fact, nuclear maspin expression in patients with stage III colon cancer is associated with response to adjuvant 5-FU-based chemotherapy and could help to select patients whose tumors do not express this molecule that may be candidates for an alternative (non-5-FU-based) adjuvant therapy regimen.

Focusing on the malignancies in which maspin showed a positive prognostic value, therapeutic approaches studied so far aimed to re-activate a dormant tumor suppressor gene by designed transcription factors, to hit the system that inhibits the expression of maspin, to identify natural substances that can determine the activation and the expression of maspin or possible "molecules binds" to introduce maspin in cancer cell and gene therapy capable of up-regulating the maspin in an attempt to reduce primarily the risk of metastasis.

Some authors hypothesized that artificial transcription factors (ATFs), composed of modular zinc finger (ZF) domains and designed to recognize specific sequences in the promoter of a tumor suppressor, would result in a reexpression of the endogenous gene silenced by epigenetic mechanisms in aggressive tumor cells (e.g. in metastatic breast cancer and in non-small cell lung cancer) and also in up-regulation of E-cadherin. Reversal and modification of the tumor suppressor epigenetic state can be achieved by blocking DNA and histone methyltransferases as well as histone deacetylases with different doses of ATFs and chromatin remodeling drugs: the methyltransferase inhibitor 5-aza-2'-deoxycytidine and the histone deacetylase inhibitor suberoylanilide hydroxamic acid. It was found that ATFs act in synergy with inhibitors in reactivating endogenous maspin expression. The strongest synergy was observed with the combination treatment ATF-126+5aza-2'-deoxycytidine + suberoylanilide hydroxamic acid. While drugs can be used to achieve the inhibition of these enzymes in an untargeted manner, the precise mechanisms and the genetic cascades whereby these drugs induce biological changes are currently not completely understood and it seems to depend on cell micro-environment. Furthermore, given that tumor suppressors sustain anti-proliferative and antimetastatic functions, it is essential to target the native tumor suppressor function in order to develop more effective therapies.

Given the clinical relevance of maspin expression in a variety of epithelial tumors (including breast, prostate, lung and colon cancer), these studies describe a novel approach to target multiple human tumors [141-148].

Recently, PAR-1 has been described to regulate the gap junction protein Connexin 43 and the maspin tumor suppressor gene to promote the metastatic melanoma phenotype. Silencing PAR-1 results in decreased activation of p38 MAPK, allowing for increased binding of c-Jun and Ets-1 transcription factors to the maspin promoter. Increased Maspin expression further inhibits cell invasion, through decreased expression and activity of MMP-2, as well as angiogenesis through decreased VEGF expression [149].

An important role of IL-6TS in decreasing adhesion and increasing motility and migration in prostate cancer, along with its effect on the inhibition of maspin was also found. Therefore, specific targeting IL-6TS in prostate cancer patients, might represent an interesting way to refine the currently available experimental anti-IL-6 therapies since sIL-6R and IL- 6 are altered in patients with a worse prognosis. This information may be helpful to identify those patients who could benefit from the anti-cytokine therapy [150].

Recent studies have investigated the use of maspin as a therapeutic agent against cancer. In one study, maspin was found to inhibit cancer growth and metastasis in a breast cancer mouse model through a maspin DNA-liposome therapy. Another study showed the ability of maspin to induce apoptosis in tumor-specific endothelial cells. Taken together, these studies demonstrate the potential use of maspin as a viable anticancer therapeutic agent [151]. Gene therapy focusing on the use of adeno-associated virus (AAV, serotype 2) vector encoding maspin in human prostate cancer was also evaluated. Immunofluorescence double staining for maspin protein and apoptosis in LNCaP tumors showed that the percentage of apoptotic cells in AAV-maspin -mediated maspin-expressing cells was significantly high if compared with that in AAV-GFP-mediated GFP-expressing cells. Moreover, significantly fewer CD31-positive microvessels were observed in AAVmaspin-treated tumors compared with the control tumors. These therapeutic responses were highly correlated to persistent maspin expression in tumors, confirmed by Western blot analysis until at least 56 days after treatment. Furthermore AAV-mediated 
prolonged maspin expression efficiently suppresses human prostate tumor growth in vivo by apoptosis induction and inhibition of angiogenesis [152].

Focusing on natural substances, it has been showed that curcumin, a hydrophobic polyphenol derived from turmeric (the rhizome of the herb Curcuma longa), is implicated in the inhibition of tumorigenesis with a combination of anti-inflammatory, anti-oxidant, immunomodulatory, pro-apoptotic, and anti-angiogenic properties via pleiotropic effects on genes and cell-signaling pathways at multiple levels, including activation of transcription factors, receptors, kinases, cytokines, enzymes and growth factors.

When curcumin is combined with some cytotoxic drugs or certain other diet-derived polyphenols, synergistic effects have been demonstrated [153-155].

Curcumin has recently received a great deal of attention as a chemoprotective agent for the prevention of colon and breast cancer and it may have clinical application in the prevention of prostate cancer. Curcumin

Table 10 summary of maspin expression

\begin{tabular}{|c|c|c|c|}
\hline Cancer & Tumor progression normal to cancer & $\begin{array}{l}\text { Positive cytoplasm or } \\
\text { positive nucleus }\end{array}$ & Prognosis \\
\hline Breast cancer & $\begin{array}{l}\text { Normal tissue: positive maspin } \\
\text { Cancer tissue }+/- \\
\text { Cancer metastasis = negative maspin }\end{array}$ & Positive nucleus = better prognosis & $\begin{array}{l}\text { Positive maspin = better/worse } \\
\text { prognosis depending of localization } \\
\text { and of epigenetic modification }\end{array}$ \\
\hline Prostate cancer & $\begin{array}{l}\text { Normal tissue: } \\
\text { Negative maspin } \\
\text { HGPI: positive maspin } \\
\text { Invasive cancer = negative maspin }\end{array}$ & $\begin{array}{l}\text { Positive nucleus increased } \\
\text { in invasive cancer }\end{array}$ & Positive maspin $=$ better prognosis \\
\hline Bladder cancer & $\begin{array}{l}\text { Normal tissue: } \\
\text { Positive maspin } \\
\text { Cancer tissue: } \\
\text { Negative maspin (T2 } \rightarrow \text { T4 positive?) }\end{array}$ & Positive nucleus = better prognosis & Positive maspin = better prognosis \\
\hline Lung cancer & $\begin{array}{l}\text { Normal tissue: positive maspin } \\
\text { Lung cancer }=\text { less positive maspin }\end{array}$ & $\begin{array}{l}\text { Positive nucleus = better prognosis } \\
\text { vs nuclear and positive cytoplasm }\end{array}$ & Positive maspin = better prognosis \\
\hline Ovarian cancer & $\begin{array}{l}\text { Normal tissue: Negative maspin } \\
\text { Early stage } \\
\text { Ovarian cancer = positive maspin } \\
\text { Metastic cancer = less positive }\end{array}$ & $\begin{array}{l}\text { Positive nucleus (rare) = better } \\
\text { prognosis }\end{array}$ & $\begin{array}{l}\text { Positive maspin = better/worse } \\
\text { prognosis depending of localization } \\
\text { and of epigenetic modification }\end{array}$ \\
\hline Colorectal cancer & $\begin{array}{l}\text { Normal tissue: negative maspin } \\
\text { Dysplasia and cancer = positive maspin }\end{array}$ & $\begin{array}{l}\text { Positive nucleus = worse prognosis } \\
\text { Positive cytoplasm better prognosis }\end{array}$ & $\begin{array}{l}\text { Positive maspin = better prognosis, } \\
\text { positive response to } 5 \mathrm{FU} \text { therapy }\end{array}$ \\
\hline Gastric cancer & $\begin{array}{l}\text { Normal tissue: positive maspin } \\
\text { Cancer tissue: negative maspin }\end{array}$ & $\begin{array}{l}\text { Positive nucleus and positive } \\
\text { cytoplasm = better prognosis vs } \\
\text { only positive cytoplasm }\end{array}$ & Positive maspin = better prognosis \\
\hline Pancreatic cancer & $\begin{array}{l}\text { Normal tissue: negative maspin } \\
\text { Pan In1, Pan In2 = negative maspin } \\
\text { Pan In3 and cancer invasive tissue = positive maspin }\end{array}$ & & Positive maspin = worse prognosis \\
\hline Gallbladder cancer & $\begin{array}{l}\text { Normal tissue: dysplasia = negative maspin } \\
\text { intestinal metastasia and cancer = positive maspin }\end{array}$ & & \\
\hline $\begin{array}{l}\text { Head and neck } \\
\text { cancer }\end{array}$ & & Positive nucleus = better prognosis & Positive maspin = better prognosis \\
\hline Thyroid cancer & $\begin{array}{l}\text { Normal tissue adenomas and follicular } \\
\text { carcinoma = negative maspin/+ papillary } \\
\text { carcinoma = positive maspin } \\
\text { Anaplastic and poorly } \\
\text { differentiated = negative maspin }\end{array}$ & & Positive maspin = better prognosis \\
\hline $\begin{array}{l}\text { Melanoma } \\
\text { malignant }\end{array}$ & $\begin{array}{l}\text { Normal tissue: positive maspin } \\
\text { Melanoma = positive maspin } \\
\text { Metastatic melanoma = negative maspin }\end{array}$ & Positive nucleus = better prognosis & Positive maspin = better prognosis \\
\hline
\end{tabular}


down-regulates the androgen receptor gene not only at the protein level but also in its transcriptional activity in androgen-depended prostate cancer. The suppression of androgen receptor transaction may affect the androgen receptor regulated genes such as maspin and curcumin increase the expression of maspin with dose and time dependence.

The mechanism utilized by curcumin to up-regulate maspin expression is unknown at this time. Nevertheless, the up-regulation only occurs in cells that have wild-type p53. This suggests that the activity of curcumin toward maspin expression may be modulated through the p53 pathway. Two other examples of nutritional compounds that have been reported to enhance tumor suppression and inhibit metastasis through up-regulation of maspin are abalone visceral extract and apple peel extract.

As in the case of curcumin, the cells treated with apple peel extract displayed significant increases in the expression of maspin [156-158].

Also resveratrol (trans-3, 49, 5-trihydroxystilbene), a polyphenolic antioxidant found in peanuts, grapes and red wine possesses significant health benefits. This compound has shown beneficial effects in experimental cancer models, where it suppresses the initiation, promotion and progression of tumors Recent studies have implicated activation of the apoptotic pathway as a mechanism accounting for the antitumor benefits of resveratrol. For example, resveratrol inhibits cell proliferation, induces apoptosis of human prostate carcinoma and acute lymphoblastic leukemia cells and increases maspin levels through Akt pathway [159-163].

\section{Conclusion}

It is important to continue to search for the maspin in different tumor types in order to better define its prognostic significance, to refine the definition techniques of cellular compartmentalization and to evaluate the possible therapeutic implications considering peculiarities of expression of maspin in various cancers (Table 10).

The correlation between the expression of maspin and clinical parameters is different depending on the type of tumor. It is likely that the lack of standardization in assessing the positivity of maspin subcellular level and the need for more studies about it can explain and permit the interpretation of differences. It would be more helpful to evaluate the expression of maspin only as a positive nucleus-cytoplasm to ensure greater uniformity of results.

\section{Competing interest}

All the authors have no financial disclosures to declare.

\section{Authors' contributions}

$\mathrm{RB}$ was responsible for the study design. RB, FM, MP, ZB, AS, MDL, MC, SR, SP, MS were responsible for literature review and interpretation. $A O, P M, C P, S C$ were responsible for literature interpretation. RB and SC were responsible for the writing of the report and the corresponding author had the final responsibility to submit for publication. All authors read and approved the final manuscript.

Received: 29 November 2012 Accepted: 28 January 2013

Published: 7 March 2013

\section{References}

1. Zou Z, Anisowicz A, Hendrix MJ, Thor A, Neveu M, Sheng S, Rafidi K, Seftor E, Sager R: Maspin, a serpin with tumor-suppressing activity in human mammary epithelial cells. Science 1994, 263(5146):526-529.

2. Klasa-Mazurkiewicz D, Narkiewicz J, Milczek T, Lipińska B, Emerich J: Maspin overexpression correlates with positive response to primary chemotherapy in ovarian cancer patients. Gynecol Oncol 2009, 113(1):91-98. Epub 2009 Feb 3.

3. Lockett J, Yin S, Li X, Meng Y, Sheng S: Tumor suppressive maspin and epithelial homeostasis. J Cell Biochem 2006, 97(4):651-660.

4. Chen El, Florens L, Axelrod FT, Monosov E, Barbas CF 3rd, Yates JR 3rd, Felding-Habermann B, Smith JW: Maspin alters the carcinoma proteome. FASEB J 2005, 19(9):1123-1124. Epub 2005 Apr 27.

5. Law RH, Irving JA, Buckle AM, Ruzyla K, Buzza M, Bashtannyk-Puhalovich TA, Beddoe TC, Nguyen K, Worrall DM, Bottomley SP, Bird PI, Rossjohn J, Whisstock JC: The high resolution crystal structure of the human tumor suppressor maspin reveals a novel conformational switch in the G-helix. J Biol Chem 2005, 280(23):22356-22364.

6. Beecken WD, Kramer W, Jonas D: New molecular mediators in tumor angiogenesis. J Cell Mol Med 2000, 4(4):262-269.

7. Pemberton PA, Wong DT, Gibson HL, Kiefer MC, Fitzpatrick PA, Sager R, Barr PJ: The tumor suppressor maspin does not undergo the stressed to relaxed transition or inhibit trypsin-like serine proteases evidence that maspin is not a protease inhibitory serpin. ASBMB 1995 270(26):15832-15837.

8. D'Andrea LD, Del Gatto A, Pedone C, Benedetti E: Peptide-based molecules in angiogenesis. Chem Biol Drug Des 2006, 67(2):115-126.

9. Vogt GR: Sticky Situations: A Story of the Rebel Mammary Serine Protease Inhibitor. Brown Deer High School Poster 2007-2008 Project: Center for bioMolecular Modeling.

10. Cella N, Contreras A, Latha K, Rosen JM, Zhang M: Maspin is physically associated with [beta]1 integrin regulating cell adhesion in mammary epithelial cells. FASEB J 2006, 20(9):1510-1512. Epub 2006 May 23.

11. Ravenhill $L$, Wagstaff $L$, Edwards DR, Ellis V, Bass R: G-helix of maspin mediates effects on cell migration and adhesion. J Biol Chem 2010, 285(47):36285-36292.

12. Seftor RE, Seftor EA, Sheng S, Pemberton PA, Sager R, Hendrix MJ: Maspin suppresses the invasive phenotype of human breast carcinoma. Cancer Res 1998, 58(24):5681-5685.

13. Zhang W, Shi HY, Zhang M: Maspin overexpression modulates tumor cell apoptosis through the regulation of $\mathrm{BCl}-2$ family proteins. BMC Cancer 2005, 5:50.

14. Shi HY, Zhang W, Liang R, Kittrell F, Templeton NS, Medina D, Zhang M: Modeling human breast cancer metastasis in mice: maspin as a paradigm. Histol Histopathol 2003, 18:201-206.

15. Affara $\mathrm{NI}$, Coussens LM: IKKa at the crossroads of inflammation and metastasis. Cell 2007, 129(1):25-26.

16. Sheng S: Maspin: a novel serine protease inhibitor. Canc Growth Progression 2005, 15:407-418.

17. Jang HL, Nam E, Lee KH, Yeom S, Son HJ, Park C: Maspin polymorphism associated with apoptosis susceptibility and in vivo tumorigenesis. Int $\mathrm{J}$ Mol Med 2008, 22(3):333-338.

18. Chen El, Yates JR: Maspin and tumor metastasis. UBMB Life. 2006, 58(1):25-29.

19. Goulet B, Chan G, Chambers AF, Lewis JD: An emerging role for the nuclear localization of maspin in the suppression of tumr progression and metastasis. Biochem Cell Biol 2012, 90(1):22-38. Epub 2011 Nov 2.

20. Zhang M, Magit D, Botteri F, et al: Maspin plays an important role in mammary gland development. Dev Biol 1999, 215:278-287.

21. Pemberton PA, Tipton AR, Pavloff N, et al: Maspin is an intracellular serpin that partitions into secretory vesicles and is present at the cell surface. $J$ Histochem Cytochem 1997, 45:1697-70613.

22. Khalkhali-Ellis Z: Maspin: the new frontier. Clin Cancer Res 2006, 12:7279-7283. 
23. Blacque $\mathrm{OE}$, Worrall DM: Evidence for a direct interaction between the tumor suppressor serpin, maspin, and types I and III collagen. J Biol Chem 2002, 277:10783

24. Khalkhali-Ellis Z, Hendrix MJ: Elucidating the function of secreted maspin: inhibiting cathepsin D-mediated matrix degradation. Cancer Res 2007, 67(8):3535-3539.

25. Goulet B, Kennette W, Ablack A, Postenka CO, Hague MN, Mymryk JS, Tuck $A B$, Giquère $V$, Chambers AF, Lewis JD: Nuclear localization of maspin is essential for its inhibition of tumor growth and metastasis. Lab Invest 2011, 91(8):1181-1187. doi:10.1038/labinvest.2011.66. Epub 2011 Apr 18.

26. Teoh SS, Whisstock JC, Bird PI: Maspin (SERPINB5) is an obligate intracellular serpin. J Biol Chem 2010, 285(14):10862-10869. Epub 2010 Feb 1.

27. Sood AK, Fletcher MS, Gruman LM, Coffin JE, Jabbari S, Khalkhali-Ellis Z, Arbour N, Seftor EA, Hendrix MJ: The paradoxical expression of maspin in ovarian carcinoma. Clin Cancer Res 2002, 8(9):2924-2932.

28. Beltran AS, Blancafort P: Reactivation of MASPIN in non-small cell lung carcinoma (NSCLC) cells by artificial transcription factors (ATFs). Epigenetics 2011, 6(2):224-235. Epub 2011 Feb 1.

29. Wu Y, Alvarez M, Slamon DJ, Koeffler P, Vadgama JV: Caspase 8 and maspin are downregulated in breast cancer cells due to $\mathrm{CpG}$ site promoter methylation. BMC Cancer 2010, 10:32.

30. Bodenstine TM, Seftor REB, Khalkhali-Ellis Z, Seftor EA, Pemberton PA, Hendrix MJC: Maspin: molecular mechanisms and therapeutic implications. Cancer Metastasis Rev December 2012, 31(3-4):529-551.

31. Bettstetter M, Woenckhaus M, Wild PJ, Rümmele P, Blaszyk H, Hartmann A, Hofstädter F, Dietmaier W: Elevated nuclear maspin expression is associated with microsatellite instability and high tumour grade in colorectal cancer. J Pathol 2005, 205(5):606-614.

32. Latha K, Zhang W, Cella N, Shi HY, Zhang M: Maspin mediates increased tumor cell apoptosis upon induction of the mitochondrial permeability transition. Mol Cell Biol 2005, 25:1737-1748.

33. Liu J, Yin S, Reddy N, Spencer C, Sheng S: Bax mediates the apoptosissensitizing effect of maspin. Cancer Res 2004, 64:1703-1711.

34. Sheng S: A role of novel serpin maspin in tumor progression: the divergence revealed through efforts to converge. J Cell Physiol 2006 209:631-635.

35. Biliran H Jr, Sheng S: Pleiotropic inhibition of pericellular urokinase-type plasminogen activator system by endogenous tumor suppressive maspin. Cancer Res 2001, 61:8676-8682.

36. Amir S, Margaryan NV, Odero-Marah V, Khalkhali-Ellis Z, Hendrix MJC: Maspin regulates hypoxia-mediated stimulation of UPA/UPAR complex in invasive breast cancer cells. Cancer Biol Ther 2005, 4:400-406.

37. Yin S, Lockett J, Meng Y, Biliran HJ, Blouse GE, Li X, Reddy N, Zhao Z, Lin X Anagli J, Cher ML, Sheng S: Maspin retards cell detachment via a novel interaction with the urokinase-type plasminogen activator/urokinasetype plasminogen activator receptor system. Cancer Res 2006 66:4173-4181

38. Ossowski L, Aguirre-Ghiso JA: Urokinase receptor and integrin partnership: coordination of signaling for cell adhesion, migration and growth. Curr Opin Cell Biol 2000, 12:613-620.

39. Odero-Marah VA, Khalkhali-Ellis Z, Chunthapong J, Amir S, Seftor RE, Seftor EA, Hendrix MJC: Maspin regulates different signaling pathways for motility and adhesion in aggressive breast cancer cells. Cancer Biol Ther 2003, 2:398-403

40. Toillon RA, Lagadec C, Page A, Chopin V, Sautière PE, Ricort JM, Lemoine J, Zhang M, Hondermarck H, Le Bourhis X: Proteomics demonstration that normal breast epithelial cells can induce apoptosis of breast cancer cells through insulin-like growth factor-binding protein-3 and maspin. Mol Cell Proteomics 2007, 6(7):1239-1247. Epub 2007 Apr 19.

41. Maass N, Teffner M, Rösel F, Pawaresch R, Jonat W, Nagasaki K, Rudolph P: Decline in the expression of the serine proteinase inhibitor maspin is associated with tumour progression in ductal carcinomas of the breast. J Pathol 2001, 195(3):321-326.

42. Joensuu KM, Leidenius MH, Andersson LC, Heikkilä PS: High expression of maspin is associated with early tumor relapse in breast cancer. Hum Pathol 2009, 40(8):1143-1151. Epub 2009 May 8.

43. Sharma G, Mirza S, Parshad R, Srivastava A, Gupta SD, Pandya P, Ralhan R: Clinical significance of Maspin promoter methylation and loss of its protein expression in invasive ductal breast carcinoma: correlation with VEGF-A and MTA1 expression. Tumour Biol 2011, 32(1):23-32. Epub 2010.
44. Hojo T, Akiyama Y, Nagasaki K, Maruyama K, Kikuchi K, Ikeda T, Kitajima M, Yamaguchi K: Association of maspin expression with the malignancy grade and tumor vascularization in breast cancer tissues. Cancer Lett 2001, 171:103-110.

45. Xia W, Lau YK, Hu MC, Li L, Johnston DA, Sheng S, El-Naggar A, Hung MC: High tumoral maspin expression is associated with improved survival of patients with oral squamous cell carcinoma. Oncogene 2000, 19:2398.

46. Umekita $Y$, Yoshida $\mathrm{H}$ : Expression of maspin is up-regulated during the progression of mammary ductal carcinoma. Histopathology 2003, 42(6):541-545.

47. Kim DH, Yoon DS, Dooley WC, Nam ES, Ryu JW, Jung KC, Park HR, Sohn JH, Shin HS, Park YE: Association of maspin expression with the high histological grade and lymphocyte-rich stroma in early-stage breast cancer. Histopathology 2003, 42(1):37-42.

48. Mohsin SK, Zhang M, Clark GM, Craig Allred D: Maspin expression in invasive breast cancer: association with other prognostic factors. J Pathol 2003, 199(4):432-435.

49. Umekita $Y$, Ohi $Y$, Sagara $Y$, Yoshida H: Expression of maspin predicts poor prognosis in breast-cancer patients. Int J Cancer 2002, 100(4):452-455.

50. Umekita Y, Ohi Y, Souda M, Rai Y, Sagara Y, Sagara Y, Tamada S, Tanimoto A: Maspin expression is frequent and correlates with basal markers in triple-negative breast cancer. Diagn Pathol 2011, 6:36.

51. Lee MJ, Suh CH, Li ZH: Clinicopathological Significance of Maspin Expression in Breast Cancer. J Korean Med Sci 2006, 21(2):309-314.

52. Stark AM, Schem C, Maass N, Hugo HH, Jonat W, Mehdorn HM, Held-Feindt $\mathrm{J}$ : Expression of metastasis suppressor gene maspin is reduced in breast cancer brain metastases and correlates with the estrogen receptor status. Neurol Res 2010, 32(3):303-308. Epub 2009 Nov 11.

53. Maass N, Hojo T, Rösel F, Ikeda T, Jonat W, Nagasaki K: Down regulation of the tumor suppressor gene maspin in breast carcinoma is associated with a higher risk of distant metastasis. Clin Biochem 2001, 34(4):303-307.

54. Pierson CR, McGowen R, Grignon D, Sakr W, Dey J, Sheng S: Maspin is upregulated in premalignant prostate epithelia. Prostate 2002, 53(4):255-262.

55. Blacque OE, Worrall DM: J: Evidence for a direct interaction between the Tumor Suppressor Serpin, Maspin, and Types I and III Collagen. Biol Chem 2002, 277:10783-10788.

56. Cher ML, Biliran HR, Bhagat S, Meng Y, Che M, Lockett J, Abrams J, Fridman $R$, Zachareas M, Sheng S, Biliran H Jr, Sheng S: Maspin expression inhibits osteolysis, tumor growth, and angiogenesis in a model of prostate cancer bone metastasis. 2003, 100(13):7847-7852.

57. Bernardo MM, Meng Y, Lockett J, Dyson G, Dombkowski A, Kaplun A, Li X, Yin S, Dzinic S, Olive M, Dean I, Krass D, Moin K, Bonfil RD, Cher M, Sakr W, Sheng S: Maspin reprograms the gene expression profile of prostate carcinoma cells for differentiation. Genes Cancer 2011, 2(11):1009-1022.

58. Neal CL, Henderson V, Smith BN, McKeithen D, Graham T, Baohan T, OderoMarah VA: Snail transcription factor negatively regulates maspin tumor suppressor in human prostate cancer cells. BMC Cancer 2012, 12:336.

59. McKenzie S, Sakamoto S, Kyprianou N: Maspin modulates prostate cancer cell apoptotic and angiogenic response to hypoxia via targeting AKT. Oncogene 2008, 27(57):7171-7179. Published online 2008 October 20.

60. Zhang M, Magit D, Sager R: Expression of maspin in prostate cells is regulated by a positive Ets element and a negative hormonal responsive element site recognized byandrogenreceptor. Cell Biology 1997, 94(11):5673-5678.

61. Tahmatzopoulos A, Sheng S, Kyprianou N: Maspin sensitizes prostate cancer cells to doxazosin-induced apoptosis. Oncogene 2005, 24(34):5375-5383.

62. Lovrić E, Gatalica Z, Eyzaguirre E, Kruslin B: Expression of maspin and glutathionine-S-transferase-pi in normal human prostate and prostatic carcinomas. Appl Immunohistochem Mol Morphol 2010, 18(5):429-432.

63. Riddick ACP, Shukla CJ, Pennington CJ, Bass R, Nuttall RK, Hogan A, Sethia KK, Ellis V, Collins AT, Maitland NJ, Ball RY, Edwards DR: Identification of degradome components associated with prostate cancer progression by expression analysis of human prostatic tissues. $\mathrm{Br} J$ Cancer 2005 92(12):2171-2180.

64. Machtens S, Serth J, Bokemeyer C, Bathke W, Minssen A, Kollmannsberger C, Hartmann J, Knüchel R, Kondo M, Jonas U, Kuczyk M: Expression of the p53 and maspin protein in primary prostate cancer: Correlation with clinical features. Int J Cancer 2001, 95:337-342.

65. Zou Z, Zhang W, Young D, Gleave MG, Rennie P, Connell T, Connelly R, Moul J, Srivastava S, Sesterhenn I: Maspin expression profile in human 
prostate cancer (CaP) and in vitro induction of Maspin expression by androgen ablation. Clin Cancer Res 2002, 8(5):1172-1177.

66. Blacque $\mathrm{OE}$, Worrall DM: Evidence for a direct interaction between the tumor suppressor serpin, maspin, and types I and II collagen. J Biol Chem 2002, 27:10783-10788.

67. Ngamkitidechakul C, Warejcka DJ, Burke JM, O'Brien WJ, Twining SS: Sufficiency of the reactive site loop of maspin for induction of cell matrix adhesion and inhibition of cell invasion. J Biol Chem 2003, 278:31796-31806.

68. Bass R, Moreno Fernandez A-M, Ellis V: Maspin inhibits cell migration in the absence of protease inhibitory activity. J Biol Chem 2002, 277:46845-46848.

69. Oshiro MM, Watts GS, Wozniak RJ, Junk DJ, Munoz-Rodriguez JL, Domann FE, Futscher BW: Mutant p53 and aberrant cytosine methylation cooperate to silence gene expression. Oncogene 2003, 22:3624-3634

70. Zhang W, Zhang M: Tissue microarray analysis of maspin expression and its reverse correlation with mutant p53 in various tumors. Int J Oncol 2002, 20:1145-1150.

71. Machtens S, Serth J, Bokemeyer C, Bathke W, Minssen A, Kollmannsberger C, Hartmann J, Knuchel R, Kondo M, Jonas U, Kuczyk M: Expression of p53 and maspin protein in primary prostate cancer: correlation with clinical features. Int J Cancer 2001, 95:337-342.

72. Marioni G, Blandamura S, Giacomelli L, Calgaro N, Segato P, Leo G, Fischetto D, Staffieri A, de Filippis C: Nuclear expression of maspin is associated with a lower recurrence rate and a longer disease-free interval after surgery for squamous cell carcinoma of the larynx. Histopathology 2005, 46:576-582.

73. Beecken WD, Engl T, Engels K, Blumenberg C, Oppermann E, Camphausen $K$, Shing $Y$, Reinecke $G$, Jonas D, Blaheta R: Clinical relevance of maspin expression in bladder cancer. World J Urol 2006, 24:338-344.

74. Montironi R, Lopez-Beltran A: The 2004 WHO classification of bladder tumors: a summary and commentary. Int I Surg Pathol 2005, 13:143-153.

75. Oosterlink W: Guidelines on diagnosis and treatment of superficial bladder cancer. Minerva Urol Nefrol 2004, 56:65-72.

76. Li Z, Shi HY, Zhang M: Targeted expression of maspin in tumor vasculatures induces endothelial cell apoptosis. Oncogene 2005, 24:2008-2019

77. Pemberton PA, Tipton AR, Pavloff N, Smith J, Erickson JR, Mouchabeck ZM, Kiefer MC: Maspin is an intracellular serpin that partitions into secretory vesicles and is present at the cell surface. J Histochem Cytochem 1997, 45:1697-1706.

78. McGowen R, Biliran H Jr, Sager R, Sheng S: The surface of prostate carcinoma DU145 cells mediates the inhibition of urokinase-type plasminogen activator by maspin. Cancer Res 2000, 60:4771-4778.

79. Woenckhaus M, Bubendorf L, Dalquen P, Foerster J, Blaszyk H, Mirlacher M, Soler M, Dietmaier W, Sauter G, Hartmann A, Wild PJ: Nuclear and cytoplasmic maspin expression in primary non-small cell lung cancer J Clin Pathol 2007, 60:483-486.

80. Acikalin D, Oner U, Can C, Acikalin MF, Ertugrul Colak E: Predictive value of maspin and Ki-67 expression in transurethral resection specimens in patients with T1 bladder cancer. Tumori 2012, 98(3):344-350.

81. Kramer MW, Waalkes S, Hennenlotter J, Serth J, Stenzl A, Kuczyk MA, Merseburger AS: Maspin protein expression correlates with tumor progression in non-muscle invasive bladder cancer. Oncol Lett. 2010, 1(4):621-626

82. Friedrich MG, Toma MI, Petri S, Cheng JC, Hammerer P, Erbersdobler A Huland $\mathrm{H}$ : Expression of Maspin in non-muscle invasive bladder carcinoma: correlation with tumor angiogenesis and prognosis. Eur Urol 2004, 45(6):737-743

83. Sugimoto S, Maass N, Takimoto Y, Sato K, Minei S, Zhang M, Hoshikawa Y, Jünemann KP, Jonat W, Nagasaki K: Expression and regulation of tumor suppressor gene maspin in human bladder cancer. Cancer Lett 2004, 203(2):209-215.

84. Nehad MR, Abd El-Maqsoud MD, Ehab Rifat Tawfiek MD: Loss of maspin expression in bladder cancer: its relationship with p53 and clinicopathological parameters. Journal of the Egyptian Nat Cancer Inst. 2010, 22(1):1-12

85. Blandamura S, D'Alessandro E, Giacomelli L, Guzzardo V, Battanello W, Repele M, Ninfo V: Expression of maspin in papillary $\mathrm{Ta} / \mathrm{T} 1$ bladder neoplasms. Anticancer Res 2008, 28(1B):471-478.
86. Nam E, Park C: Maspin suppresses survival of lung cancer cells through modulation of Akt pathway. Cancer Res Trea 2010, 42(1):42-47. Epub 2010 Mar 31.

87. Bircan A, Bircan S, Kapucuoglu N, Songur N, Ozturk O, Akkaya A: Maspin: VEGF and p53 expression in small biopsies of primary advanced lung cancer and relationship with clinicopathologic parameters. Pathol Oncol Res 2010, 16(4):553-561.

88. Lonardo F, Li X, Siddiq F, Singh R, Al-Abbadi M, Pass HI, Sheng S: Maspin nuclear localization is linked to favorable morphological features in pulmonary adenocarcinoma. Lung Cancer 2006, 51(1):31-39. Epub 2005 Sep 12.

89. Frey A, Soubani AO, Adam AK, Sheng S, Pass HI, Lonardo F: Nuclear, compared with combined nuclear and cytoplasmic expression of maspin, is linked in lung adenocarcinoma to reduced VEGF-A levels and in Stage I, improved survival. Histopathology 2009, 54(5):590-597. Epub 2009 Mar 20.

90. Hirai K, Koizumi K, Haraguchi S, Hirata T, Mikami I, Fukushima M, Yamagishi S, Kawashima T, Okada D, Shimizu K, Kawamoto M: Prognostic significance of the tumor suppressor gene maspin in non-small cell lung cancer. Ann Thorac Surg 2005, 79(1):248-253.

91. Berardi R, Santinelli A, Onofri A, Brunelli A, Pierantoni C, Pisa E, Pagliacci A, Stramazzotti D, Zuccatosta L, Mazzanti P, Sabbatini A, Gasparini S, Bearzi I, Cascinu S: Maspin expression is a favorable prognostic factor in nonsmall cell lung cancer. Anal Quant Cytol Histol 2012, 34(2):72-78.

92. Wu S, Yu L, Cheng Z, Song W, Zhou L, Tao Y: Expression of maspin in nonsmall cell lung cancer and its relationship to vasculogenic mimicry. J Huazhong Univ Sci Technolog Med Sci 2012, 32(3):346-352. Epub 2012 Jun 9.

93. Nakagawa M, Katakura H, Adachi M, Takenaka K, Yanagihara K, Otake Y, Wada $\mathrm{H}$, Tanaka F: Maspin expression and its clinical significance in nonsmall cell lung cancer. Ann Surg Oncol 2006, 13(11):1517-1523.

94. Katakura H, Takenaka K, Nakagawa M, Sonobe M, Adachi M, Ito S, Wada H, Tanaka F: Maspin gene expression is a significant prognostic factor in resected non-small cell lung cancer (NSCLC). Maspin in NSCLC. Lung Cancer 2006, 51(3):323-328. Epub 2006 Jan 6.

95. Takanami I, Abiko T, Koizumi S: Expression of maspin in non-small-cell lung cancer: correlation with clinical features. Clin Lung Cancer 2008, 9(6):361-366.

96. Lin Z, Liu Y, Sun Y, He X: Expression of Ets-1, Ang-2 and maspin in ovarian cancer and their role in tumor angiogenesis. Clin Cancer Res 2002, 8(9): 2924-2932. Journal of Experimental \& Clinical Cancer Research 2011, 30:31.

97. Gynecologic oncology group, Secord AA, Lee PS, Darcy KM, Havrilesky LJ, Grace LA, Marks JR, Berchuck A: Maspin expression in epithelial ovarian cancer and associations with poor prognosis: a gynecologic oncology group study. Gynecol Oncol 2006, 101:390-397.

98. Moshira Mohamad Abd El Wahed MD: Expression and Subcellular Localization of Maspin in Human Ovarian Epithelial Neoplasms: Correlation with Clinicopathologic Features. Journal of the Egyptian Nat. Cancer Inst 2005, 17(3):173-183.

99. Sopel M, Surowiak P, Berdowska I: Nuclear maspin expression as a good prognostic factor in human epithelial ovarian carcinoma. Folia Morphol (Warsz) 2010, 69(4):204-212.

100. Solomon LA, Munkarah AR, Schimp VL, Arabi MH, Morris RT, Nassar H, AliFehmi R: Maspinexpression and localization impact on angiogenesis and prognosis in ovarian cancer. Gynecol Oncol 2006, 101(3):385-389.

101. Bolat F, Gumurdulu D, Erkanli S, Kayaselcuk F, Zeren H, Ali Vardar M, Kuscu E: Maspin overexpression correlates with increased expression of vascular endothelial growth factors $A, C$, and D in human ovarian carcinoma. Pathol Res Pract 2008, 204(6):379-387. Epub 2008 Mar 17.

102. Bauerschlag DO, Habermann M, Weimer J, Meinhold-Heerlein I, Hilpert F, Weigel M, Bauer M, Mundhenke C, Jonat W, Maass N, Schem C: Heterogeneous expression of serine protease inhibitor maspin in ovarian cancer. Anticancer Res 2010, 30(7):2739-2744.

103. Cao D, Wilentz RE, Abbruzzese JL, Ho L, Maitra A: Aberrant expression of maspin in idiopathic inflammatory bowel disease is associated with disease activity and neoplastic transformation. Int J Gastrointest Cancer 2005, 36(1):39-46.

104. Song SY, Lee SK, Kim DH, Son HJ, Kim HJ, Lim YJ, Lee WY, Chun HK, Rhee $J C$ : Expression of maspin in colon cancers: its relationship with p53 expression and microvessel density. Dig Dis Sci 2002, 47(8):1831-1835.

105. Ni JT, Yi YF, Shi HP: Expressions of maspin, P53 and Skp2 in colorectal 
tumors and their clinicopathological significance. Chin J Canc Res 2009, 21(2):147-153.

106. Zheng H, Tsuneyama K, Cheng C, Takahashi H, Cui Z, Murai Y, Nomoto K, Takano Y: Maspin expression was involved in colorectal adenomaadenocarcinoma sequence and liver metastasis of tumors. Anticancer Res 2007, 27:259-266.

107. Umekita Y, Souda M, Yoshida H: Expression of maspin in colorectal cancer. In Vivo 2006, 20(6B):797-800.

108. Fung CL-S, Chan C, Jankova L, Dent OF, Robertson G, Molloy M, Bokey L, Chapuis PH, Lin BPC, Clarke SJ: Clinicopathological correlates and prognostic significance of maspin expression in 450 patients after potentially curative resection of node-positive colonic cancer. Histopathology 2010, 56:319-330.

109. Gurzu S, Szentirmay Z, Toth E, Jung I: Possible predictive value of maspin expression in colorectal cancer. Recent Pat Anticancer Drug Discov 2012. PMID 22963136.

110. Märkl B, Arnholdt HM, Jähnig H, Schenkirsch G, Herrmann RA, Haude K, Spatz H, Anthuber M, Schlimok G, Oruzio D: Shift from cytoplasmic to nuclear maspin expression correlates with shorter overall survival in node-negative colorectal cancer. Hum Pathol 2010, 41(7):1024-1033. Epub 2010 Mar 23

111. Dietmaier W, Bettstetter M, Wild PJ, Woenckhaus M, Rümmele P, Hartmann A, Dechant S, Blaszyk H, Pauer A, Klinkhammer-Schalke M, Hofstädter F: Nuclear Maspin expression is associated with response to adjuvant 5-fluorouracil based chemotherapy in patients with stage III colon cancer. Int J Cancer 2006, 118(9):2247-54

112. Kim M, Ju H, Lim B, Kang C: Maspin genetically and functionally associates with gastric cancer by regulating cell cycle progression. Carcinogenesis 2012, 33(12):2344-50.

113. Wang MC, Yang YM, Li XH, Dong F, Li Y: Maspin expression and its clinicopathological significance in tumorigenesis and progression of gastric cancer. World J Gastroenterol 2004, 10(5):634-7.

114. Lee DY, Park CS, Kim HS, Kim JY, Kim YC, Lee S: Maspin and p53 protein expression in gastric adenocarcinoma and its clinical applications. Appl Immunohistochem Mol Morphol 2008, 16(1):13-8.

115. Liu H, Shi J, Anandan V, Wang HL, Diehl D, Blansfield J, Gerhard G, Lin F: Reevaluation and identification of the best immunohistochemical panel (pVHL, Maspin, S100P, IMP-3) for ductal adenocarcinoma of the pancreas. Arch Pathol Lab Med 2012, 136(6):601-9.

116. Maass N, Hojo T, Ueding M, Lüttges J, Klöppel G, Jonat W, Nagasaki K: Expression of the tumor suppressor gene Maspin in human pancreatic cancers. Clin Cancer Res 2001, 7(4):812-7.

117. Maesawa C, Ogasawara S, Yashima-Abo A, Kimura T, Kotani K, Masuda S, Nagata Y, Iwaya T, Suzuki K, Oyake T, Akiyama Y, Kawamura H, Masuda T: Aberrant maspin expression in gallbladder epithelium is associated with intestinal metaplasia in patients with cholelithiasis. J Clin Pathol 2006, 59:328-330.

118. Kim J, Jang KT, Hyun Kim K, Wook Park J, Jin Chang B, Hyuck Lee K, Kyun Lee J, Seok Heo J, Choi SH, Wook Choi D, et al: Aberrant maspin expression is involved in early carcinogenesis of gallbladder cancer. Tumor Biology 2010, 31(5):471-476.

119. Xia W, Lau YK, Hu M-T, et al: High tumoral maspin expression is associated with improved survival of patients with oral squamous cell carcinoma. Oncogene 2000, 19:2398-403.

120. Yasumatsu R, Nakashima T, Hirakawa N, et al: Maspin expression in stage I and II oral tongue squamous cell carcinoma. Head Neck 2001, 23:962-6.

121. Yoshizawa K, Nozaki S, Kitahara H, Kato K, Noguchi N, Kawashiri S, Yamamoto E: Expression of urokinase-type plasminogen activator/ urokinase-type plasminogen activator receptor and maspin in oral squamous cell carcinoma: Association with mode of invasion and clinicopathological factors. Oncol Rep 2011, 26(6):1555-60.

122. Yoshizawa K, Nozaki S, Okamune A, Kitahara H, Ohara T, Kato K, Kawashiri S, Yamamoto $\mathrm{E}$ : Loss of maspin is a negative prognostic factor for invasion and metastasis in oral squamous cell carcinoma. J Oral Pathol Med 2009, 38(6):535-539. Epub 2009 Mar 13.

123. lezzi G, Piattelli A, Rubini C, Goteri G, Artese L, Perrotti V, Carinci F: Maspin expression in oral squamous cell carcinoma. J Craniofac Surg 2007,
18(5):1039-43

124. Marioni G, Gaio E, Giacomelli L, Bertolin A, D'Alessandro E, Stramare R, Facco E, Staffieri A, Blandamura S: MASPIN subcellular localization and expression in oral cavity squamous cell carcinoma. Eur Arch Otorhinolaryngol 2008, 265(Suppl 1):S97-S104. Epub 2008 Jan 31.

125. Marioni G, Blandamura S, Lionello M, Giacomelli L, Staffieri C, Fasanaro E, Manzato E, Staffieri A: Nuclear MASPIN expression relates to a better prognosis in elderly patients with laryngeal carcinoma. Acta Otolaryngol 2011, 131(11):1220-1225. Epub 2011 Jul 6.

126. Ito Y, Yoshida H, Tomoda C, Uruno T, Takamura Y, Miya A, Kobayashi K, Matsuzuka F, Matsuura N, Kuma K, Miyauchi A: Maspin expression is directly associated with biological aggressiveness of thyroid carcinoma. Thyroid 2004, 14(1):13-8.

127. Boltze C, Schneider-Stock R, Meyer F, Peters B, Quednow C, Hoang-Vu C, Roessner A: Maspin in thyroid cancer: its relationship with p53 and clinical outcome. Oncol Rep 2003, 10(6):1783-7.

128. Boltze C, Hoang-Vu C, Schneider-Stock R, Lehnert H, Roessner A: Role of the class II tumor suppressor gene maspin in thyroid carcinogenesis. Verh Disch Ges Pathol 2004, 88:237-45.

129. Tahany M, Shams MD, Rehab M, Samaka MD, Mohamed E, Shams MD: Maspin protein expression: a special feature of papillary thyroid carcinoma. Journal of the Egyptian Nat. Cancer Inst 2006, 18(3):274-280.

130. Villares GJ, Zigler M, Dobroff AS, Wang H, Song R, Melnikova VO, Huang L, Braeuer RR, Bar-Eli M: Protease activated receptor-1 inhibits the Maspin tumor-suppressor gene to determine the melanoma metastatic phenotype. Proc Natl Acad Sci USA 2011, 108(2):626-631.

131. Denk AE, Bettstetter M, Wild PJ, Hoek K, Bataille F, Dietmaier W, Bosserhoff AK: Loss of maspin expression contributes to a more invasive potential in malignant melanoma. Pigment Cell Res 2007, 20(2):112-9.

132. Domann FE, Rice JC, Hendrix MJ, Futscher BW: Epigenetic silencing of maspin gene expression in human breast cancers. Int J Cancer 2000, 85(6):805-10.

133. Futscher BW, Oshiro MM, Wozniak RJ, Holtan N, Hanigan CL, Duan H, Domann FE: Role for DNA methylation in the control of cell type specific maspin expression. Nat Genet 2002, 31(2):175-179. Epub 2002 May 20.

134. Wada K, Maesawa C, Akasaka T, Masuda T: Aberrant expression of the maspin gene associated with epigenetic modification in melanoma cells. J Invest Dermatol 2004, 122(3):805-11.

135. Chua R, Setzer S, Govindarajan B, Sexton D, Cohen C, Arbiser JL: Maspin expression, angiogenesis, prognostic parameters, and outcome in malignant melanoma. J Am Acad Dermatol 2009, 60(5):758-66.

136. Sabbatini R, Federico M, Morselli M, Depenni R, Cagossi K, Luppi M, Torelli $G$, Silingardi C: Detection of circulating tumor cells by reverse transcriptase polymerase chain reaction of maspin in patients with breast cancer undergoing conventional-dose chemotherapy. J Clin Oncol 2000, 18:1914-1920.

137. Ferrucci PF, Rabascio C, Mazzetta C, et al: Mammaglobin expression in leukapheresis is a products predictive marker of poor prognosis in women high-risk with breast cancer. Clin Cancer Res 2004, 10:6039-6046.

138. Leone F, Perissinotto E, Viale A, Cavalloni G, Taraglio S, Capaldi A, Piacibello W, Torchio B, Aglietta M: Tumour cell contamination detection of breast cancer cell contamination in leukapheresis product by real-time quantitative polymerase chain reaction. Bone Marrow Transplant 2001, 27:517-523

139. López-Guerrero JA, Gilabert PB, González EB, Sanz Alonso MA, Pérez JP, Talens AS, Oraval EA, de la Rubia CJ, Boix SB: Use of reverse-transcriptase polymerase chain reaction (RT-PCR) for carcinoembryonic antigen, cytokeratin 19, and maspin in the detection of tumor cells in leukapheresis products from patients with breast cancer: comparison with immunocytochemistry. J Hematother 1999, 8(1):53-61.

140. Marioni G, Koussis H, Gaio E, Giacomelli L, Bertolin A, D'Alessandro E, Scola A, Ottaviano G, de Filippis C, Jirillo A, Staffieri A, Blandamura S: MASPIN's prognostic role in patients with advanced head and neck carcinoma treated with primary chemotherapy (carboplatin plus vinorelbine) and radiotherapy: preliminary evidence. Acta Otolaryngol 2009, 129(7):786-92.

141. Beltran A, Parikh S, Liu Y, Cuevas BD, Johnson GL, Futscher BW: Re-activation of a dormant tumor suppressor gene maspin by designed transcription factors. Oncogene 2007, 26:2791-2798. 
142. Beltran AS, Blancafor P: Reactivation of MASPIN in non-small cell lung carcinoma (NSCLC) cells by artificial transcription factors (ATFs). Epigenetics 2011, 6(2):224-235.

143. Zardo G, Fazi F, Travaglini L, Nervi C: Dynamic and reversibility of heterochromatic gene silencing in human disease. Cell Res 2005, 15:679-690.

144. Baylin SB, Ohm JE: Epigenetic gene silencing in cancer-a mechanism for early oncogenic pathway addiction? Nat Rev Cancer 2006, 6:107-116.

145. Cameron EE, Bachman KE, Myohanen S, Herman JG, Baylin SB: Synergy of demethylation and histone deacetylase inhibition in the reexpression of genes silenced in cancer. Nat Genet 1999, 21:103-107.

146. Yatabe Y, Mitsudomi T, Takahashi T: Maspin expression in normal lung and non-small-cell lung cancers: cellular property-associated expression under the control of promoter DNA methylation. Oncogene 2004, 23:4041-4049.

147. Hurtubise A, Momparler RL: Evaluation of antineo-plastic action of 5-aza $-2^{\prime}$ - deoxycytidine (Dacogen) and docetaxel (Taxotere) on human breast, lung and prostate carcinoma cell lines. Anticancer Drugs 2004, 15:161-167.

148. Beltran AS, Sun X, Lizardi PM, Blancafort P: Reprogramming epigenetic silencing: artificial transcription factors synergize with chromatin remodeling drugs to reactivate the tumor suppressor mammary serine protease inhibitor. Mol Cancer Ther 2008, 7(5):1080-90.

149. Villares GJ, Maya Z, Menashe B-E: The emerging role of the thrombin receptor (par-1) in melanoma metastasis - a possible therapeutic target. Oncotarget 2011, 2:8-17.

150. Santer FR, Malinowska K, Culig Z, Cavarretta IT: Interleukin-6 transsignalling differentially regulates proliferation, migration, adhesion and maspin expression in human prostate cancer cells. Endocr Relat Cancer 2010, 17(1):241-53.

151. Schaefer JS, Zhang M: Targeting maspin in endothelial cells to induce cell apoptosis. Expert Opin Ther Targets 2006, 10(3):401-8.

152. Watanabe M, Nasu Y, Kashiwakura Y, Kusumi N, Tamayose K, Nagai A, Sasano T, Shimada T, Daida H, Kumon H: Adeno-associated virus 2-mediated intratumoral prostate cancer gene therapy: long-term maspin expression efficiently suppresses tumor growth. Hum Gene Ther 2005, 16(6):699-710.

153. Strimpakos AS, Sharma RA: Curcumin: Preventive and Therapeutic Properties in Laboratory Studies and Clinical Trials. Antioxid Redox Signal 2008, 10(3):511-546.

154. Anand P, Sundaram C, Jhurani S, Kunnumakkara AB, Aggarwal BB: Curcumin and cancer: An "old-age" disease with an "age-old" solution. Cancer Lett 2008, 267:133-164.

155. Prasad CP, Rath G, Mathur S, Bhatnagar D, Ralhan R: Potent growth suppressive activity of curcumin in human breast cancer cells: Modulation of Wnt/beta-catenin signaling. Chem Biol Interact 2009, 181(2):263-271.

156. Tsoli E, Tsantoulis PK, Papalambros A, Perunovic B, England D, Rawlands DA, Reynolds GM, Vlachodimitropoulos D, Morgan SL, Spiliopoulou CA, Athanasiou T, Gorgoulis VG: Simultaneous evaluation of maspin and CXCR4 in patients with breast cancer. J Clin Pathol 2007, 60(3):261-266.

157. Reagan-Shaw S, Eggert D, Mukhtar H, Ahmad N: Antiproliferative effects of apple peel extract against cancer cells. Nutr Cancer 2010, 62(4):517-524.

158. Altenburg JD, Siddiqui RA: The Beneficial Effects of Nutritional Compounds on Breast Cancer Metastasis. In Breast Cancer Current and Alternative Therapeutic Modalities. Edited by Esra G. ISBN: 2011:978-953-307776-5, InTech, Available from:http://www.intechopen.com/books/breastcancer-currentand.

159. Fremont L: Biological effects of resveratrol. Life Sci 2000, 66:663-673.

160. Maxwell S, Cruickshank A, Thorpe G: Red wine and antioxidant activity in serum. Lancet 1994, 344:193-194.

161. Yu W, Fu YC, Wang W: Cellular and molecular effects of resveratrol in health and disease. J Cell Biochem 2011, 113:752-759.

162. Jang M, Cai L, Udeani GO, Slowing KV, Thomas CF, et al: Cancer chemopreventive activity of resveratrol, a natural product derived from grapes. Science 1997, 275:218-220.

163. Sheth S, Jajoo S, Kaur T, Mukherjea D, Sheehan K, et al: Resveratrol reduces prostate cancer growth and metastasis by inhibiting the Akt/MicroRNA-21 Pathway. PLoS One 2012, 7(12):e51655. doi:10.1371/journal.pone.0051655.

doi:10.1186/2001-1326-2-8

Cite this article as: Berardi et al: Role of maspin in cancer. Clinical and Translational Medicine 2013 2:8.

\section{Submit your manuscript to a SpringerOpen ${ }^{\circ}$ journal and benefit from:}

- Convenient online submission

- Rigorous peer review

- Immediate publication on acceptance

- Open access: articles freely available online

- High visibility within the field

- Retaining the copyright to your article

Submit your next manuscript at $\gg$ springeropen.com 